\title{
Biogas upgrading and utilization: Current status and perspectives
}

Angelidaki, Irini; Treu, Laura; Tsapekos, Panagiotis; Luo, Gang; Campanaro, Stefano; Wenzel, Henrik; Kougias, Panagiotis

Published in:

Biotechnology Advances

Link to article, DOI:

10.1016/j.biotechadv.2018.01.011

Publication date:

2018

Document Version

Peer reviewed version

Link back to DTU Orbit

Citation (APA):

Angelidaki, I., Treu, L., Tsapekos, P., Luo, G., Campanaro, S., Wenzel, H., \& Kougias, P. (2018). Biogas upgrading and utilization: Current status and perspectives. Biotechnology Advances, 36(2), 452-466. https://doi.org/10.1016/j.biotechadv.2018.01.011

\section{General rights}

Copyright and moral rights for the publications made accessible in the public portal are retained by the authors and/or other copyright owners and it is a condition of accessing publications that users recognise and abide by the legal requirements associated with these rights.

- Users may download and print one copy of any publication from the public portal for the purpose of private study or research.

- You may not further distribute the material or use it for any profit-making activity or commercial gain

- You may freely distribute the URL identifying the publication in the public portal 
See discussions, stats, and author profiles for this publication at: https://www.researchgate.net/publication/322684018

\section{Biogas upgrading and utilization: Current status and perspectives}

Article in Biotechnology advances · January 2018

DOI: 10.1016/j.biotechadv.2018.01.011

\section{CITATIONS}

66

7 authors, including:

Irini Angelidaki

Technical University of Denmark

516 PUBLICATIONS 21,626 CITATIONS

SEE PROFILE

(2)

Panagiotis Tsapekos

Technical University of Denmark

42 PUBLICATIONS 351 CITATIONS

SEE PROFILE
READS

3,050

Some of the authors of this publication are also working on these related projects:

Enrichment of anaerobic mixed culture for biogas upgrading and chemicals production View project

MicrobStopNH3-Innovative bioaugmentation strat-egies to tackle ammonia inhibition in an-aerobic digestion process View project 
Research review paper

\title{
Biogas upgrading and utilization: Current status and perspectives
}

\author{
Irini Angelidaki ${ }^{\mathrm{a}}$, Laura Treu ${ }^{\mathrm{a}}$, Panagiotis Tsapekos ${ }^{\mathrm{a}}$, Gang Luo ${ }^{\mathrm{c}}$, Stefano Campanaro ${ }^{\mathrm{b}}$, \\ Henrik Wenzel $^{\mathrm{d}}$, Panagiotis G. Kougias ${ }^{\mathrm{a}, *}$ \\ ${ }^{a}$ DTU-Environment, Technical University of Denmark, 2800 Kgs., Lyngby, Denmark \\ ${ }^{\mathrm{b}}$ Environmental Science and Engineering, Fudan University, Shanghai 200433, China \\ c Department of Biology, University of Padua, Via U. Bassi 58/b, Padova 35121, Italy \\ ${ }^{\mathrm{d}}$ Life Cycle Engineering, University of Southern Denmark, Odense 5230, Denmark
}

\section{A R T I C L E I N F O}

\section{Keywords:}

Biogas upgrading

Methanation

Biogas utilization

Biogas purification

Biomethane

Hydrogenation

\begin{abstract}
A B S T R A C T
Biogas production is an established sustainable process for simultaneous generation of renewable energy and treatment of organic wastes. The increasing interest of utilizing biogas as substitute to natural gas or its exploitation as transport fuel opened new avenues in the development of biogas upgrading techniques. The present work is a critical review that summarizes state-of-the-art technologies for biogas upgrading and enhancement with particular attention to the emerging biological methanation processes. The review includes comprehensive description of the main principles of various biogas upgrading methodologies, scientific and technical outcomes related to their biomethanation efficiency, challenges that have to be addressed for further development and incentives and feasibility of the upgrading concepts.
\end{abstract}

\section{Introduction}

Biogas is the product of a biologically mediated process, which is known as Anaerobic Digestion (AD). Biogas primarily consists of methane $\left(\mathrm{CH}_{4}\right)$ in a range of $50-70 \%$ and carbon dioxide $\left(\mathrm{CO}_{2}\right)$ at a concentration of $30-50 \%$. The relative content of $\mathrm{CH}_{4}$ and $\mathrm{CO}_{2}$ in biogas is mainly dependent on the nature of the substrate and $\mathrm{pH}$ of the reactor. Besides these two gasses, biogas additionally contains minor amounts of other compounds, such as nitrogen $\left(\mathrm{N}_{2}\right)$ at concentrations of $0-3 \%$, which could originate from air saturated in the influent, vapour water $\left(\mathrm{H}_{2} \mathrm{O}\right)$ at concentrations of 5-10\%, or higher at thermophilic temperatures, derived from medium evaporation, oxygen $\left(\mathrm{O}_{2}\right)$ at concentrations of $0-1 \%$, which is entering the process from the influent substrate or leakages, hydrogen sulfide $\left(\mathrm{H}_{2} \mathrm{~S}\right)$ at concentrations of $0-10,000 \mathrm{ppmv}$, which is produced from reduction of sulfate contained in some wastestreams, ammonia $\left(\mathrm{NH}_{3}\right)$ originating from hydrolysis of proteinaceous materials or urine, hydrocarbons at concentrations of $0-200 \mathrm{mg} / \mathrm{m}^{-3}$ and siloxanes at concentrations of $0-41 \mathrm{mg} \mathrm{m}^{-3}$, originating for example from effluents from cosmetic medical industries (Muñoz et al., 2015; Petersson and Wellinger, 2009).

Apart from $\mathrm{CH}_{4}$, all the other gasses contained in biogas are unwanted and are considered as biogas pollutants. The energy content of methane described by the Lower Calorific Value (LCV) is $50.4 \mathrm{MJ} / \mathrm{kg}$ $\mathrm{CH}_{4}$ or $36 \mathrm{MJ} / \mathrm{m}^{3}-\mathrm{CH}_{4}$ (at STP conditions). Therefore, it is well understood that the higher the $\mathrm{CO}_{2}$ or $\mathrm{N}_{2}$ content is, the lower the LCV in biogas. For biogas with methane content in the range of $60-65 \%$ the LCV is approximately $20-25 \mathrm{MJ} / \mathrm{m}^{3}$-biogas. $\mathrm{H}_{2} \mathrm{~S}$ and $\mathrm{NH}_{3}$ are toxic and extremely corrosive, damaging the combined heat and power (CHP) unit and metal parts via emission of $\mathrm{SO}_{2}$ from combustion. Moreover, the presence of siloxanes in biogas, even in minor concentrations, is associated with problems. It is well known that during combustion silicone oxides generate sticky residues which deposit in biogas combustion engines and valves causing malfunction (Abatzoglou and Boivin, 2009). Nowadays, there are different treatments targeting at removing the undesired compounds from the biogas expanding its range of applications.

The first treatment is related to "biogas cleaning" and includes removal of harmful and/or toxic compounds (such as $\mathrm{H}_{2} \mathrm{~S}$, Si, volatile organic compounds (VOCs), siloxanes, $\mathrm{CO}$, and $\mathrm{NH}_{3}$ ). However, it is practically only $\mathrm{H}_{2} \mathrm{~S}$ which is mainly targeted and many current biogas plants have $\mathrm{H}_{2} \mathrm{~S}$ removal units commonly based on biological $\mathrm{H}_{2} \mathrm{~S}$ oxidation by aerobic sulphate oxidizing bacteria. The second treatment is called "biogas upgrading" and aims to increase the low calorific value of the biogas, and thus, to convert it to higher fuel standard (Sun et al., 2015). In case the upgraded biogas is purified to specifications similar to natural gas, the final gas product is called biomethane (Kougias et al., 2017b). Currently, the specifications of the natural gas composition are depending on national regulations and in some countries $>95 \%$ methane content is required; however, European Commission has recently issued a mandate for determining harmonised standards for gas quality.

\footnotetext{
* Corresponding author.

E-mail address: panak@env.dtu.dk (P.G. Kougias).
} 


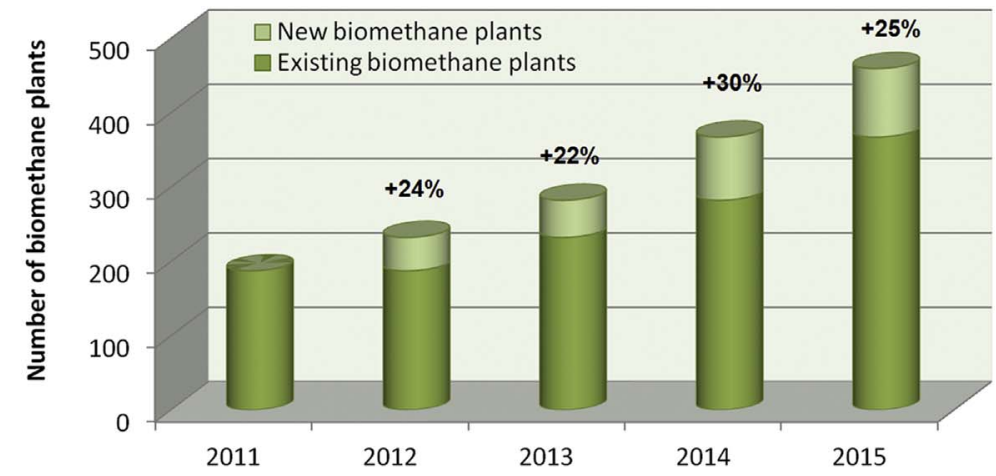

(a)

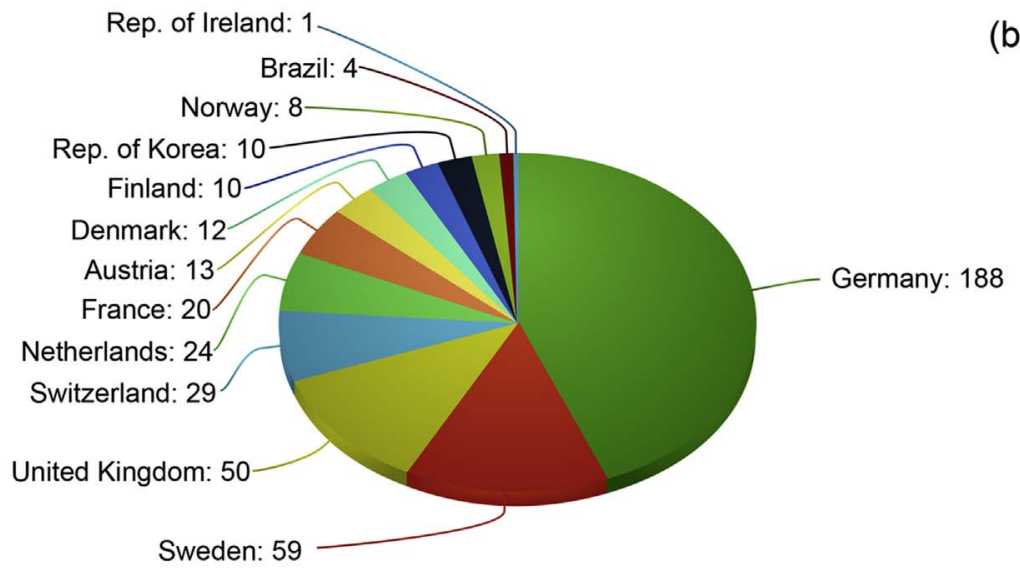

(b)

(c)
Fig. 1. Development of biogas upgrading technologies distributed according to countries and years; a) number of operating biomethane plants, b) location of existing biomethane plants and c) distribution of applied commercial technologies. Data are according to IEA Bioenergy Task 37 as reported in Hoyer et al. (2016) and European Biogas Association.

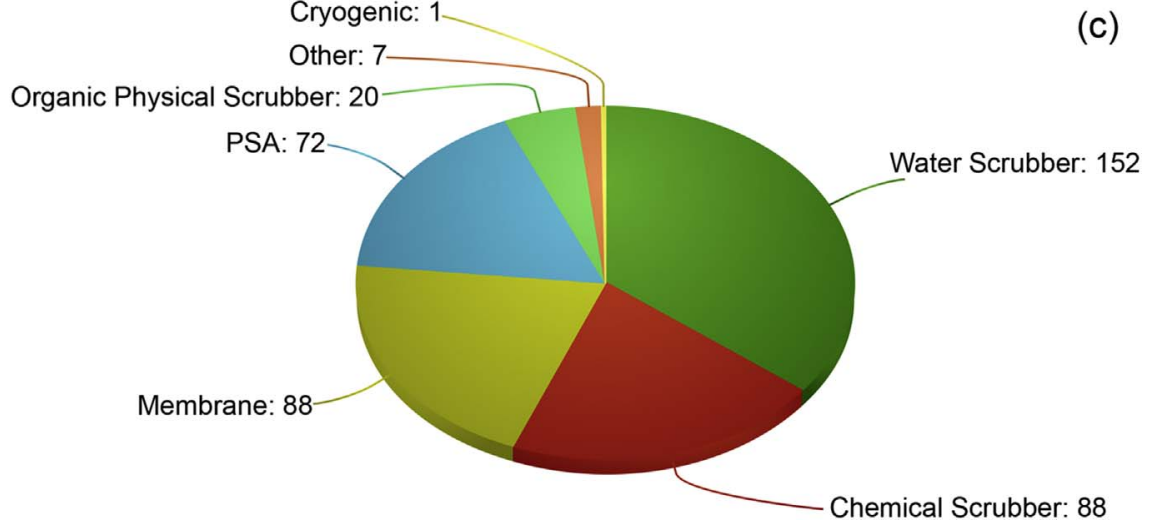

It should be noted that in the upgrading process the $\mathrm{CO}_{2}$ contained in the raw biogas is either removed or is converted to $\mathrm{CH}_{4}$ by reaction with $\mathrm{H}_{2}$ (Kougias et al., 2017b). There are several commercial upgrading technologies available. An increasing number of biogas plants with biogas upgrading units are emerging in Europe the recent years (Fig. 1a). Most of the biomethanation plants are in Germany, while other European countries such Sweden, UK, Switzerland and have also constructed biomethanation facilities (Fig. 1b).

The aim of the present work is to provide a comprehensive overview of various biogas upgrading technologies and to present incentives for further development of upgrading concepts. More specifically, the review describes the main principles of commercial or under development physical, chemical and biological methodologies. Particular attention has been given to emerging upgrading bioprocesses since they are envisioned to play a protagonist role in decoupling bioenergy production from biomass availability. Finally, the review presents technoeconomic and environmental incentives that encourage the sustainability perspective of biogas upgrading concepts.

\section{Biogas upgrading technologies}

\subsection{Physical and chemical technologies}

Currently, five physical/chemical technologies for separation/ transformation of $\mathrm{CO}_{2}$ from $\mathrm{CH}_{4}$ exist at commercial readiness level (Fig. 1c), involving processes of absorption, adsorption and membrane separation. Moreover, there are other technologies based on cryogenic process or chemical hydrogenation, which are still under development. A more detailed description of the functional principles and the status of these biogas upgrading technologies is given in the next subchapters and a comparison of their biomethanation efficiencies is given at Table 1. In general, the methane recovery from physicochemical processes can reach $>96 \%$ and as it will be further discussed increased temperature, high pressure or addition of chemicals are required to ensure an efficient biomethanation. 
Table 1

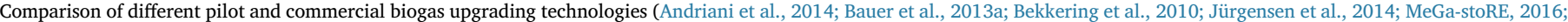
Muñoz et al., 2015; Ryckebosch et al., 2011; Serejo et al., 2015; Toledo-Cervantes et al., 2017).

\begin{tabular}{|c|c|c|c|c|c|c|c|}
\hline & Cryogenic & Sabatier process & PSA & Water scrubbing & Physical scrubbing & Chemical absorption & Membrane separation \\
\hline Consumption for raw biogas $\left(\mathrm{kWh} / \mathrm{Nm}^{3}\right)$ & 0.76 & $\mathrm{nf}$ & $0.23-0.30$ & $0.25-0.3$ & $0.2-0.3$ & $0.05-0.15$ & $0.18-0.20$ \\
\hline Consumption for clean biogas $(\mathrm{kWh} / \mathrm{Nm} 3)$ & $\mathrm{nf}$ & $\mathrm{nf}$ & $0.29-1.00$ & $0.3-0.9$ & 0.4 & $0.05-0.25$ & $0.14-0.26$ \\
\hline Heat consumption $\left(\mathrm{kWh} / \mathrm{Nm}^{3}\right)$ & $\mathrm{nf}$ & $\mathrm{nf}$ & None & None & $<0.2$ & $0.5-0.75$ & None \\
\hline Heat demand $\left({ }^{\circ} \mathrm{C}\right)$ & -196 & 270 & & & $55-80$ & $100-180$ & \\
\hline Cost & High & Medium & Medium & Medium & Medium & High & High \\
\hline $\mathrm{CH}_{4}$ losses (\%) & 2 & $\mathrm{nf}$ & $<4$ & $<2$ & $2-4$ & $<0.1$ & $<0.6$ \\
\hline $\mathrm{CH}_{4}$ recovery (\%) & $97-98$ & $97-99$ & $96-98$ & $96-98$ & $96-98$ & $96-99$ & $96-98$ \\
\hline Pre-purification & Yes & Recommended & Yes & Recommended & Recommended & Yes & Recommended \\
\hline $\mathrm{H}_{2} \mathrm{~S}$ co-removal & Yes & No & Possible & Yes & Possible & Contaminant & Possible \\
\hline $\mathrm{N}_{2}$ and $\mathrm{O}_{2}$ co-removal & Yes & No & Possible & No & No & No & Partial \\
\hline Operation pressure (bar) & 80 & $8-10$ & $3-10$ & $4-10$ & $4-8$ & Atmospheric & $5-8$ \\
\hline Pressure at outlet (bar) & $8-10$ & & $4-5$ & $7-10$ & $1.3-7.5$ & $4-5$ & 4.-6 \\
\hline
\end{tabular}

nf: not found
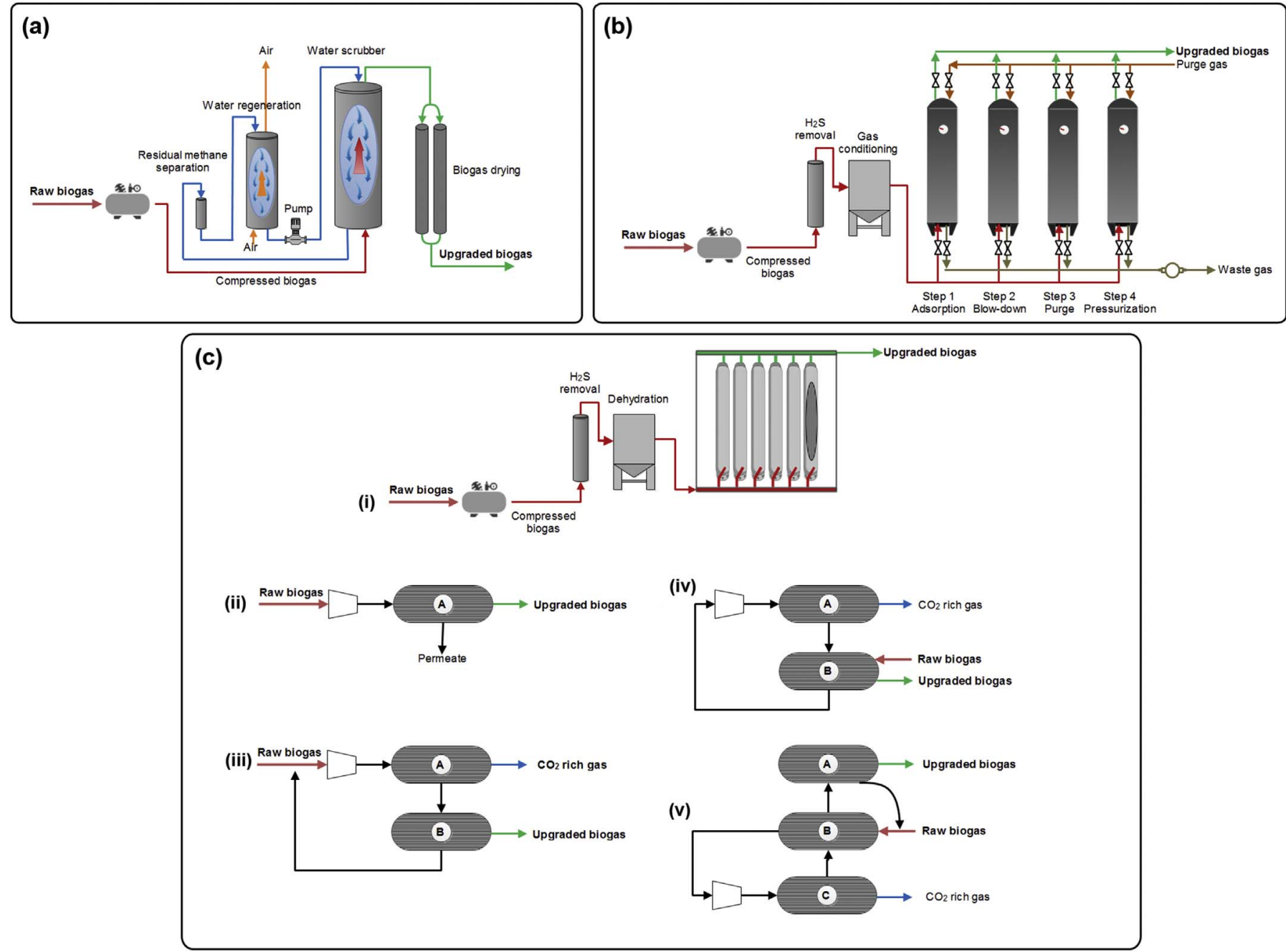

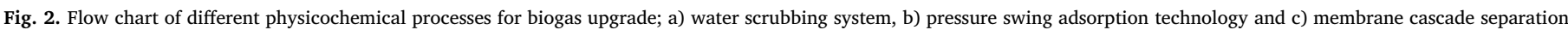

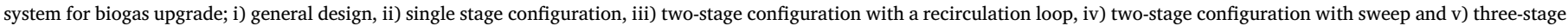
configuration with sweep. Modified based on Bauer et al. (2013b), Makaruk et al. (2010), and Zhao et al. (2010).

\subsubsection{Physical absorption method using water scrubbing system}

Water scrubbing (Fig. 2a) is the most commonly used technology for biogas cleaning and upgrading (Thrän et al., 2014). This process relies on the separation of $\mathrm{CO}_{2}$ and $\mathrm{H}_{2} \mathrm{~S}$ from the biogas due to their increased solubility in water compared to $\mathrm{CH}_{4}$ (i.e. according to Henry's law, the solubility of $\mathrm{CO}_{2}$ in water at $25{ }^{\circ} \mathrm{C}$ is approximately 26 times higher compared to methane). Initially, the biogas is pressurized (6-10 bar, up to $40{ }^{\circ} \mathrm{C}$ ) and injected into the absorption column via the bottom side of the tank, while the water is provided from the top (Bauer et al., 2013b). On contrary, water is provided from the top side of the column and flows towards the counter-current flow of the gas. The absorption column is usually filled with random packing material to increase the gas-liquid mass transfer (Ryckebosch et al., 2011). The biomethane is released from the top of the scrubber, while the water phase containing 
the $\mathrm{CO}_{2}$ and $\mathrm{H}_{2} \mathrm{~S}$ is circulated into a flush column, where the pressure decreases (2.5-3.5 bar) and some traces of $\mathrm{CH}_{4}$ which were dissolved in the water are recovered. Depending on the water re-use, two methods are commercially available; the "single pass scrubbing", which is employed in cases that the water is derived from sewage treatment plants and the "regenerative absorption". In the latter one, the water can be regenerated in a desorption column by decompression at atmospheric pressure, resulting in the removal of $\mathrm{CO}_{2}$ and $\mathrm{H}_{2} \mathrm{~S}$. Water decompression usually occurs by air stripping. However, in cases that the biogas contains high concentrations of $\mathrm{H}_{2} \mathrm{~S}$, steam or inert gas are used in the desorption process to avoid formation of elemental sulphur by the application of air stripping, which will in turn lead to operational problems (Ryckebosch et al., 2011). The regeneration step is crucial for this upgrading technology due to the large quantities of water that are required. The typical water flow that is needed to upgrade $1000 \mathrm{Nm}^{3} / \mathrm{h}$ of raw biogas ranges between 180 and $200 \mathrm{~m}^{3} / \mathrm{h}$ depending on the pressure and water temperature (Bauer et al., 2013a). Finally, after a drying step, the $\mathrm{CH}_{4}$ can reach up to $99 \%$ purity (Sun et al., 2015).

\subsubsection{Physical absorption method using organic solvents}

This method relies on the same principle as water scrubbing, however, the absorption of $\mathrm{CO}_{2}$ and $\mathrm{H}_{2} \mathrm{~S}$ is accomplished by the use of organic solvent instead of water (Table 1). Commonly, the used organic solvents are mixtures of methanol and dimethyl ethers of polyethylene glycol. Marketable chemical products are available under the trade names of Selexol ${ }^{\circledR}$ and Genosorb ${ }^{\circledR}$. The advantage of the solvents compared to the water relies to the considerably higher solubility of $\mathrm{CO}_{2}$ that can be exhibited. More specifically, Selexol ${ }^{\circledast}$ is able to absorb 3 times more $\mathrm{CO}_{2}$ than water, which practically means reduced liquid inputs in the system, and therefore, smaller dimensions of the upgrading unit. Nevertheless, the organic solvents are difficult to be regenerated due to the high solubility of $\mathrm{CO}_{2}$ and this constitutes a major obstacle of the process (Persson, 2003). Furthermore, the solubility of $\mathrm{H}_{2} \mathrm{~S}$ in Selexol ${ }^{\circledast}$ is significantly higher than the one of $\mathrm{CO}_{2}$ and therefore its separation during the solvent regeneration requires increased temperatures. It is obvious that the more the concentration of $\mathrm{H}_{2} \mathrm{~S}$ in the raw biogas is, the higher the temperature should be applied. Thus, to avoid increased energy consumption it is recommended to remove $\mathrm{H}_{2} \mathrm{~S}$ before the gas is fed to the solvent (Persson, 2003). Initially, the raw biogas is compressed (7-8 bars) and is cooled at around $20^{\circ} \mathrm{C}$ prior to its injection from the bottom of the absorption column. Similarly, the organic solvent is cooled down prior to its addition as the temperature affects the Henry's constant (Bauer et al., 2013a). Afterwards, the organic solvent is regenerated by heating it up to $80{ }^{\circ} \mathrm{C}$ and adding it in a desorption column in which the pressure is decreased to 1 bar (Bauer et al., 2013b; Sun et al., 2015). The final content of $\mathrm{CH}_{4}$ in the upgraded biogas using this technology can reach 98\% (Bauer et al., 2013a).

\subsubsection{Chemical absorption method using amine solutions}

Chemical scrubbers use aqueous amine solutions (i.e. mono-, di- or tri-ethanolamine) to bind the $\mathrm{CO}_{2}$ molecules contained in the biogas. One of the advantages of this technology is that $\mathrm{H}_{2} \mathrm{~S}$ can also be completely absorbed in the amine scrubber. Amine scrubbing systems mainly consists of an absorber unit and a stripper. In the absorption column, the biogas (at a pressure of 1-2 bars) is provided from the bottom of the tank while the amine solution flows in a counter-current fashion from the top. The $\mathrm{CO}_{2}$ is bound into the solvent by an exothermic chemical reaction. Subsequently, the resultant rich in $\mathrm{CO}_{2}$ and $\mathrm{H}_{2} \mathrm{~S}$ amine solution is routed to a stripping unit for regeneration. The stripping column has a pressure of 1.5-3 bars and is equipped with a boiler that provides heat attaining the temperature at $120-160{ }^{\circ} \mathrm{C}$. The heat aims to disrupt the chemical bonds formed in the absorber phase and also to create a vapour stream that acts as stripping fluid. Finally, the steam that contains $\mathrm{CO}_{2}$ is cooled in a condenser allowing the condensate to recirculate to the stripper and the entrapped $\mathrm{CO}_{2}$ to be released. Apart from amine solutions, other aqueous alkaline salts, such as sodium, potassium and calcium hydroxides, can be involved in order the solvent to chemically react with the $\mathrm{CO}_{2}$ (Kougias et al., 2010; Zhao et al., 2010). In principle, sodium hydroxide has higher $\mathrm{CO}_{2}$ absorption capacity compared to amine-based solvents such as mono-ethanolamine. More specifically, in order to capture 1 ton of $\mathrm{CO}_{2}$, the theoretical amount of mono-ethanolamine that will be needed reaches 1.39 tons, while the corresponding amount of sodium hydroxide is 0.9 tons (Yoo et al., 2013). Main disadvantages of this method include the toxicity of the solvents to human and environment, the significant energy that is needed for regeneration of the chemical solutions, the initial cost of the amine solvents and their loss due to evaporation. Therefore, aqueous alkaline salts are preferred in comparison with amines as they are more cost efficient and more abundant (Yoo et al., 2013). By applying this technology, the final methane content in the output gas can reach $99 \%$ purity due to the fact that the chemical reaction is strongly selective and thus the methane loss can be lower than $0.1 \%$ (Table 1 ).

\subsubsection{Pressure swing adsorption (PSA)}

This technology separates the different gasses from biogas based on their molecular characteristics and the affinity of the adsorbent material (Fig. 2b). The adsorbents can be carbon molecular sieve, activated carbon, zeolites (Zeolite $13 \times$, Zeolite 5A) and other material with high surface area (Augelletti et al., 2017). The main principle of PSA technology relies on the properties of pressurized gasses to be attracted to solid surfaces. Therefore, under high pressure, large amounts of gas will be adsorbed, while, a decrease of pressure will result in gas release. The PSA process follows four equal or different duration steps, namely adsorption, blow-down, purge and pressurization (Augelletti et al., 2017). Initially, the compressed biogas (4-10 bars) is injected into an adsorption vessel (column), in which the adsorbent material will selectively retain $\mathrm{CO}_{2}, \mathrm{~N}_{2}, \mathrm{O}_{2}, \mathrm{H}_{2} \mathrm{O}$ and $\mathrm{H}_{2} \mathrm{~S}$, while the methane is able to flow through it and can be collected from the top of the column by decreasing the pressure. In practice, multiple adsorption columns are installed (usually four) to ensure the maintenance of a continuous operation (Bauer et al., 2013b). Once the adsorbent is saturated, the gas stream will continue to the next column. In the saturated column, the adsorbent material will be regenerated by a desorption process, in which the pressure is decreased and the entrapped gasses are released. The gas mixture that is released from the columns contains significant amounts of methane, and therefore, it has to be recycled by leading it to the PSA inlet (Awe et al., 2017). On contrary, the adsorption of $\mathrm{H}_{2} \mathrm{~S}$ is normally irreversible and for that reason it has to be removed prior the injection of the biogas to the PSA column (Zhao et al., 2010). This method is advantageous due to equipment compactness, it requires low energy and capital investment cost, and finally, due to its safety and simplicity of operation (Augelletti et al., 2017). The raw biogas can be upgraded up to $96-98 \%$ methane concentration; however, up to $4 \%$ methane can be lost within the off-gas stream (Table 1) (Bauer et al., 2013a; Ryckebosch et al., 2011).

\subsubsection{Membrane separation}

Membrane technology is a competitive alternative to the conventional absorption based biogas upgrading system. The main principle of the technology relies on the selective permeability properties of membranes allowing the separation of the biogas components. For example, based on the relative permeation rates, the different molecules contained in biogas permeation can be ordered hierarchically from the slowest to the faster permeation as follows $\mathrm{C}_{3} \mathrm{H}_{8}, \mathrm{CH}_{4}, \mathrm{~N}_{2}, \mathrm{H}_{2} \mathrm{~S}, \mathrm{CO}_{2}$ and $\mathrm{H}_{2} \mathrm{O}$ (Bauer et al., 2013a). Depending on the separation media, the process can either be performed with dry (gas/gas separation) or wet (gas/liquid separation) techniques (Fig. 2c). The dry process uses specific membranes (mainly polymeric). The materials of the polymeric membranes able to separate $\mathrm{CO}_{2}$ and $\mathrm{CH}_{4}$ are cellulose acetate and polyimide (Baker, 2012). The permeation rate of such membranes is dependent on the sorption coefficients of the gasses and on the membrane construction material, which in turn, affects the mobility 
selectivity (Baker, 2012). The sorption coefficient of a gas depends on condensability of the permeant, and thus, smaller molecules are normally less condensable compared to larger ones. On contrary, the diffusion coefficient decreases with increasing molecular size. Considering the diffusion and the sorption coefficient of different gasses as a function of their molar volume, it can be observed that smaller molecules (e.g. $\mathrm{CO}_{2}$ ) are less condensable and more favourable to become permeant from the membrane compared to larger molecules (e.g. $\mathrm{CH}_{4}$ ) (Baker, 2012). Therefore, in many polymeric membranes the diffusion coefficient and the solubility of $\mathrm{CO}_{2}$ is higher compared to $\mathrm{CH}_{4}$ resulting in higher permeability. Consequently, the gas that is rich in $\mathrm{CH}_{4}$ will remain to the side of the membrane with the higher pressure, while the $\mathrm{CO}_{2}$ (together with a significant amount of methane that can reach $10-15 \%)$ will be diffused to the side with the lower pressure. In real practice, the raw biogas is initially cleaned by removing contaminants such as water and $\mathrm{H}_{2} \mathrm{~S}$ to avoid problems related to corrosion (Persson, 2003). Afterwards, the biogas is compressed at 5-20 bars prior to its injection to the membrane unit (Bauer et al., 2013b). The $\mathrm{CO}_{2}$ separation efficiency is strictly dependant on the type and material of the membrane used. An ideal membrane should have large permeability difference between $\mathrm{CH}_{4}$ and $\mathrm{CO}_{2}$ so as to minimise the $\mathrm{CH}_{4}$ losses and efficiently purify the biogas. Currently, there are four main manufacturing configurations for gas/gas membrane cascades (Fig. 2c); the single stage, the two-stage with a recirculation loop, the two-stage with sweep biogas stream and the three-stage with sweep biogas stream (Makaruk et al., 2010). Therefore, as it can be evidenced, single stage configurations (Fig. 2c ii) are simpler, do not include internal rotating equipment, as the two-stage with recirculation loop (Fig. 2c iii), and require less maintenance (Baker, 2012), contributing in minimising the operational cost. Moreover, in two-stage with sweep (Fig. 2c iv), the biogas stream exiting the membrane cascade $B$ is recirculated so as to be mixed with the influent gas and subsequently fed to membrane A as a sweep steam. Finally, the three-stage with sweep biogas stream (Fig. 2c v) has an additional cascade and constitutes a low pressure feed membrane composed by both enriching and stripping sections. The $\mathrm{CH}_{4}$ content in the upgraded biogas is commonly $95 \%$ but it can reach > 98\% under certain conditions (Table 1) (Bauer et al., 2013a).

The difference between the dry and the wet process is related to the hydrophobic properties of the micro-porous membranes used in the latter one. The wet membrane technology combines the advantages of the membranes with those from the absorption method. Practically, the installed membrane separates the gas feed and the liquid, and the gas molecules are able to diffuse through the membrane and be absorbed by the liquid media that flows counter-wise. The liquid solution can be regenerated under high temperature, while the released $\mathrm{CO}_{2}$ is pure and can be exploited in other industrial applications. Major disadvantages of this technology are the high cost of the membranes and also that they are fragile. It is estimated that the lifetime of the membranes for biogas purification varies between 5 and 10 years (Bauer et al., 2013a).

\subsubsection{Cryogenic separation process}

This technology is conducted through a gradual decrease of biogas temperature separating the liquefied $\mathrm{CH}_{4}$ from both $\mathrm{CO}_{2}$ and rest components (Muñoz et al., 2015) in order to obtain a product in accordance with the quality standards for Liquefied Natural Gas (LNG) (Grande and Blom, 2014). The separation is carried out by initially drying and compressing the raw biogas up to 80 bars followed by a stepwise temperature drop up to $-110{ }^{\circ} \mathrm{C}$ (Ryckebosch et al., 2011). Thus, the low contained impurities (i.e. $\mathrm{H}_{2} \mathrm{O}, \mathrm{H}_{2} \mathrm{~S}$, siloxanes, halogens etc.) and subsequently, $\mathrm{CO}_{2}$ which is the second most dominant component of biogas are gradually removed in order to recover almost pure biomethane ( $>97 \%$ ). Despite the promising results, the cryogenic separation process is still under development and only few facilities are operating in commercial scale (Bauer et al., 2013a). The high investment and operation costs, losses of $\mathrm{CH}_{4}$ and practical problems (e.g. clogging) derived from either the increased concentration of solid $\mathrm{CO}_{2}$ or presence of rest impurities limit the wider establishment of this technique (Bauer et al., 2013a; Muñoz et al., 2015; Ryckebosch et al., 2011).

\subsubsection{Chemical hydrogenation process}

The reduction of $\mathrm{CO}_{2}$ with $\mathrm{H}_{2}$ can be either conducted biologically (presented in following subchapter) or chemically, based on Sabatier reaction. Regarding the chemical hydrogenation process, various catalysts, with Nickel and Ruthenium to be the most commonly used in industrial applications (Jürgensen et al., 2015), have already been tested under elevated temperature (e.g. $300{ }^{\circ} \mathrm{C}$ ) and pressure levels (e.g. 5-20 MPa) (Xia et al., 2016). Due to high selectivity, complete conversion of $\mathrm{CO}_{2}$ and $\mathrm{H}_{2}$ can be practically achieved (Jürgensen et al., 2014). Nevertheless, despite the high process efficiency, specific drawbacks still remain. For instance, the sustainability is affected by the presence of trace gasses in the biogas, which degenerate the catalysts leading to increased need for periodical replacement (Guebitz et al., 2015). Additional technical challenges of the process are the scarcity of elements to synthesize efficient catalysts, the need for pure gasses and the high energy cost to maintain the operational conditions.

\subsection{Biological technologies}

The biological biogas upgrading technologies can be generally classified into chemoautotrophic and photosynthetic. Most of these configurations have been experimentally proven and are at an early stage of pilot or full scale implementation. As it will be discussed extensively, the major advantage of such technologies is related to the fact that the $\mathrm{CO}_{2}$ is converted into other energy containing or high value added products at mild operational conditions (i.e. atmospheric pressure, moderate temperature levels) contributing significantly to a sustainable bio-based and circular economy.

\subsubsection{Chemautotrophic methods}

The chemoautotrophic biogas upgrading methods are based on the action of hydrogenotrophic methanogens that can utilise $\mathrm{H}_{2}$ to convert $\mathrm{CO}_{2}$ to $\mathrm{CH}_{4}$ based on the following equation:

$4 \mathrm{H}_{2}+\mathrm{CO}_{2} \rightarrow \mathrm{CH}_{4}+\mathrm{H}_{2} \mathrm{O} \quad \Delta G^{0}=-130.7 \mathrm{KJ} / \mathrm{mol}$

However, in order to make the biological upgrading method renewable, the $\mathrm{H}_{2}$ required in the reaction should derive from renewable source. Therefore, the concept of using renewable electricity to hydrolyse water for production of $\mathrm{H}_{2}$ has attracted increased attention, especially in cases that residual electricity from wind mills or solar panels exploiting is exploited. This method is also serving the purpose of storing the surplus energy generated by wind turbines or photovoltaic modules creating a new technology called power to gas (P2G). Solar and wind energy are point energy sources which need buffering for delivering the energy when it is dark and the wind is still. Batteries used for electricity storage have still several drawbacks such as low capacity for storing large amounts of electricity, high production cost, and often require toxic and caustic materials. Water electrolysis using renewable electricity is splitting the water to $\mathrm{O}_{2}$ and $\mathrm{H}_{2}$. In such way, the generation of $\mathrm{H}_{2}$, which is an energy carrier by itself, is a clean power source free of $\mathrm{CO}_{2}$ emissions. However, $\mathrm{H}_{2}$ has some disadvantages before a practical application is possible. More specifically, $\mathrm{H}_{2}$ has the inherent disadvantage of a very low volumetric energy density, which renders difficult its storage (Jürgensen et al., 2014). Additionally, the exploitation of $\mathrm{H}_{2}$ as a fuel for the transportation sector is still under development (Muñoz et al., 2015). Therefore, integration of P2G technology for conversion of $\mathrm{H}_{2}$ to $\mathrm{CH}_{4}$ is very attractive as it integrates wind or solar energy technology with biogas technology. This process is a promising means to convert electricity to a chemical energy carrier, which can easily be stored in the existing natural gas infrastructure. The energy content of $\mathrm{CH}_{4}\left(36 \mathrm{MJ} / \mathrm{m}^{3}\right)$ is remarkably higher compared with the corresponding one of $\mathrm{H}_{2}$ 


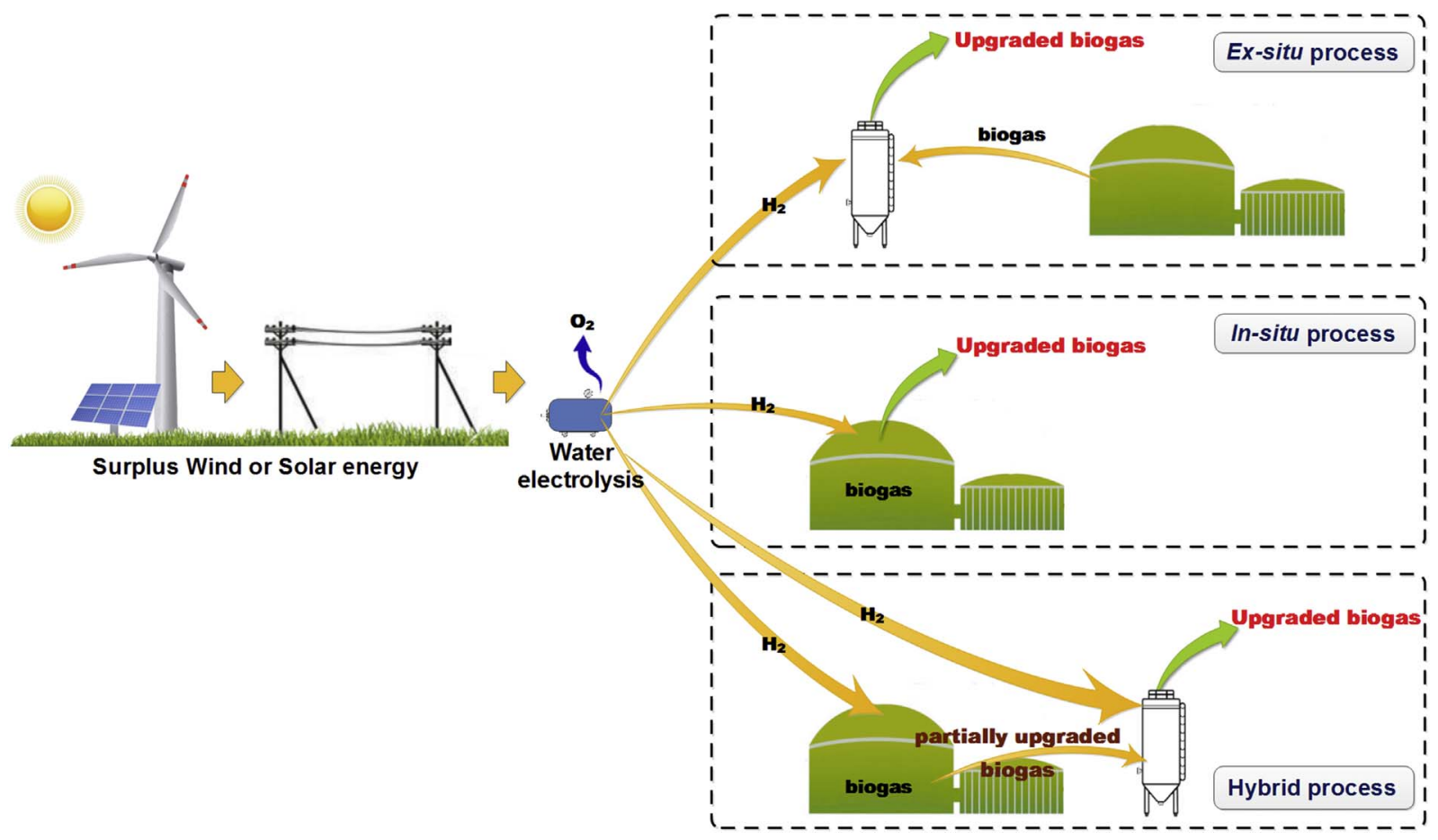

Fig. 3. In-situ, ex-situ and hybrid biological biogas upgrading technologies based on hydrogen methanation.

$\left(10.88 \mathrm{MJ} / \mathrm{m}^{3}\right.$ ) (Luo et al., 2012). Moreover, the upgrading process exploits the existing facilities of the biogas plants and therefore reduces the initial investment cost. Furthermore, during the chemoautotrophic methods, the $\mathrm{CO}_{2}$ is not separated or absorbed but converted to $\mathrm{CH}_{4}$ leading to a significant increment of the final energy value of the output "windgas" (i.e. methane produced using the surplus energy from wind turbines) or "solargas" (i.e. methane produced using the surplus energy from solar panels) (Kougias et al., 2017b). Finally, this technology serves as a precondition for the sustainability of the ambitious biogas implementation plan of decoupling the biogas production from the biomass availability. The configurations in which hydrogen assisted biogas upgrading occurs can be classified into three categories (Fig. 3), namely in-situ, ex-situ and hybrid designs (Kougias et al., 2017b). Till now, the in-situ and ex-situ processes are experimentally proven and several research works are available in the literature. On the contrary, the hybrid concept is currently under development and the first results related to that technology will be soon available.

2.2.1.1. In-situ biological biogas upgrading. In the in-situ concept, $\mathrm{H}_{2}$ is injected inside a biogas reactor in order to be coupled with the endogenous $\mathrm{CO}_{2}$ which is produced in the anaerobic digester and be converted into $\mathrm{CH}_{4}$ by the action of autochthonous methanogenic archaea (Kougias et al., 2017b). As seen in Table 2, the process can lead up to approximately $99 \%$ methane recovery only in cases that operational parameters (e.g. $\mathrm{pH}$ ) are fully monitored and controlled. A main technical challenge that this technology faces is related with the increment of $\mathrm{pH}$ level to values above 8.5, leading to inhibition of methanogenesis. The elevation of $\mathrm{pH}$ is attributed to the removal of bicarbonate which is the key buffer in the biogas process. As shown in Eq. (2), $\mathrm{CO}_{2}$ dissolved in the liquid phase of the reactor is dissociated to $\mathrm{H}^{+}$and $\mathrm{HCO}_{3}{ }^{-}$. The utilization of $\mathrm{CO}_{2}$ will lead to a decrease of $\mathrm{H}^{+}$, causing a concomitant increase in the fermentation $\mathrm{pH}$.

$\mathrm{H}_{2} \mathrm{O}+\mathrm{CO}_{2} \leftrightarrow \mathrm{H}^{+}+\mathrm{HCO}_{3}^{-}$

Previous experiments in in-situ biogas upgrading reactors showed a slight inhibition of methanogenesis due to bicarbonate consumption (Luo et al., 2012) verifying the argument that in conventional biogas production systems a $\mathrm{pH}$ of 8.5 is the threshold for optimum biomethanation process both for mesophilic and thermophilic conditions (Bassani et al., 2015). In order to alleviate this technical challenge, codigestion with acidic waste was proposed to arrest increase of $\mathrm{pH}$ (Luo and Angelidaki, 2013a). More specifically, it was demonstrated that the co-digestion of manure with cheese whey wastewater maintained the $\mathrm{pH}$ in an optimal range during the whole biogas upgrading process. An alternative approach to circumvent this challenge was the application of $\mathrm{pH}$ control permitting successful upgrading to almost pure biomethane (Luo et al., 2014).

Another important issue that has to be considered during the in-situ

Table 2

Comparison of in-situ biological upgrading processes.

\begin{tabular}{|c|c|c|c|c|c|c|c|c|c|}
\hline Reactor type & Substrate & Temperature, ${ }^{\circ} \mathrm{C}$ & HRT, d & $\mathrm{H}_{2}$ flow, L/L/d & $\begin{array}{l}\mathrm{H}_{2} \text { conversion } \\
\text { efficiency, } \%\end{array}$ & $\mathrm{CH}_{4}, \%$ & $\begin{array}{l}\mathrm{CO}_{2} \text { removal, } \\
\%\end{array}$ & $\mathrm{pH}$ & Reference \\
\hline Batch & Maize leaf & 52 & & & 100 & 89.4 & $66-70$ & $7.0-8.0$ & (Mulat et al., 2017) \\
\hline UASB & Potato-starch & 55 & 7 & 1.8 & 67 & 82 & 76 & 8.38 & (Bassani et al., 2016) \\
\hline CSTR & Cattle manure & 55 & 14 & 0.68 & $>90$ & 65 & & 8.3 & (Luo et al., 2012) \\
\hline CSTR & $\begin{array}{l}\text { Cattle manure and } \\
\text { whey }\end{array}$ & 55 & 15 & 1.7 & & 75 & 85 & $7.7-7.9$ & $\begin{array}{l}\text { (Luo and Angelidaki, } \\
\text { 2013a) }\end{array}$ \\
\hline CSTR & Sludge & 38 & 20 & $0.3-1.7$ & $58-99$ & $76.8-100$ & $43.3-100$ & $7.89-8.43$ & (Agneessens et al., 2017) \\
\hline CSTR & $\begin{array}{l}\text { Cattle manure and } \\
\text { whey }\end{array}$ & 55 & 15 & $0.93-1.76$ & & $78.4-96.1$ & $53-91$ & $7.61-8.31$ & $\begin{array}{l}\text { (Luo and Angelidaki, } \\
\text { 2013b) }\end{array}$ \\
\hline CSTR & Sewage sludge & 37 & 10 & 0.92 & 96 & 98.9 & 99 & 8 & (Wang et al., 2013) \\
\hline
\end{tabular}


process is related with the oxidation of the Volatile Fatty Acids (VFA) and alcohols which is only thermodynamically feasible in cases that $\mathrm{H}_{2}$ concentration is very low (Batstone et al., 2002). On contrary, high $\mathrm{H}_{2}$ levels ( $>10 \mathrm{~Pa}$ ) inhibit the anaerobic digestion, and promote the accumulation of electron sinks such as lactate, ethanol, propionate, and butyrate (Liu and Whitman, 2008). It would be expected that if sudden and high $\mathrm{H}_{2}$ concentrations are introduced in the biogas reactor the VFA degradation would no longer be possible (Batstone et al., 2002). As a consequence, the system could become imbalanced or even, in the worst case, can totally be fatally deteriorated due to excess acidification caused by VFA accumulation. A recent study concluded that the injection of $\mathrm{H}_{2}$ in batch reactors at a concentration that exceeds the stoichiometric amount for hydrogenotrophic methanogenesis led to an accumulation of acetate, which could be attributed to stimulated homoacetogenic pathway, and/or decreased methanogenic activity of acetoclastic archaea (Agneessens et al., 2017). However, after longer term $\mathrm{H}_{2}$ exposure, increase of the hydrogenotrophic population enhances the $\mathrm{H}_{2}$-utilization capacity and reverts the inhibition (Reeve et al., 1997).

An additional key parameter is the solubilisation of $\mathrm{H}_{2}$ to the liquid phase as it must cross the interface between the gas and the liquid phase in order to be available for the microorganisms. Thus, the aqueous solubility of most gasses is rather low, which limits the gas-liquid mass transfer and hampers the performance of the bioreactor (Tirunehe and Norddahl, 2016). For that reason, the material and type of the module that is used to inject $\mathrm{H}_{2}$, the application of gas recirculation flows and the reactor designs are considered as fundamental elements for the implementation of sufficient in-situ biogas upgrading (Bassani et al., 2016). In batch experiments, it was found that the $\mathrm{H}_{2}$ uptake rate decreased rapidly at $\mathrm{CO}_{2}$ concentrations $<12 \%$ (Agneessens et al., 2017) and the maximum $\mathrm{CH}_{4}$ content in biogas reached 89\% (Mulat et al., 2017). On contrary in continuously fed reactors, Luo and Angelidaki (2013b) who used hollow fiber membranes to inject $\mathrm{H}_{2}$ in an anaerobic reactor treating cattle manure and cheese whey, achieved up to $96 \%$ methane at the final output gas. In another research performed in upflow anaerobic sludge blanket reactor, hollow fiber membrane was installed in an external degassing unit and the obtained efficiency of the in-situ biogas upgrading reached 94\% (Luo et al., 2014). However, as the cost of such membranes has to be considered for full scale applications, other porous devices, such as ceramic sponges, have been proven to benefit the coupling of $\mathrm{CO}_{2}$ and $\mathrm{H}_{2}$ and their consequent transformation to $\mathrm{CH}_{4}$ (Bassani et al., 2016). A comparison of different in-situ configurations is presented in Table 2.

2.2.1.2. Ex-situ biological biogas upgrading. The ex-situ biogas upgrade concept relies to the provision of $\mathrm{CO}_{2}$ from external sources and $\mathrm{H}_{2}$ in an anaerobic reactor that contains (pure or enriched) hydrogenotrophic culture, resulting in their subsequent conversion to $\mathrm{CH}_{4}$ (Kougias et al., 2017b). This method has several advantages compared to the in-situ process as; a) it secures the stability of the conventional biogas process because the upgrading is occurring in a separate unit, b) the biochemical process is simpler since there is no degradation of organic substrate (i.e. initial steps of anaerobic digestion, such as hydrolysis and acidogenesis are not performed), c) it is a biomass independent process, d) other external source of waste $\mathrm{CO}_{2}$ (e.g. syngas) can be used making the process more flexible, and e) by this process it is feasible to supply power to remote from the centralized grid rural areas. As evidenced by Table 3, the ex-situ process can handle high volumes of influent gasses decreasing the gas retention time even to $1 \mathrm{~h}$, which minimises the dimensions of the biogas upgrading chamber. The biogas upgrading efficiency, strongly depending on the reactor type, can result in final methane content between 79 and $98 \%$. Technical challenge in this technology remains the low gas-liquid mass transfer rate, which in case of $\mathrm{H}_{2}$ is described by the following equation:

$r_{t}=22.4 k_{L} a\left(\mathrm{H}_{2 g T h}-\mathrm{H}_{2 l}\right)$

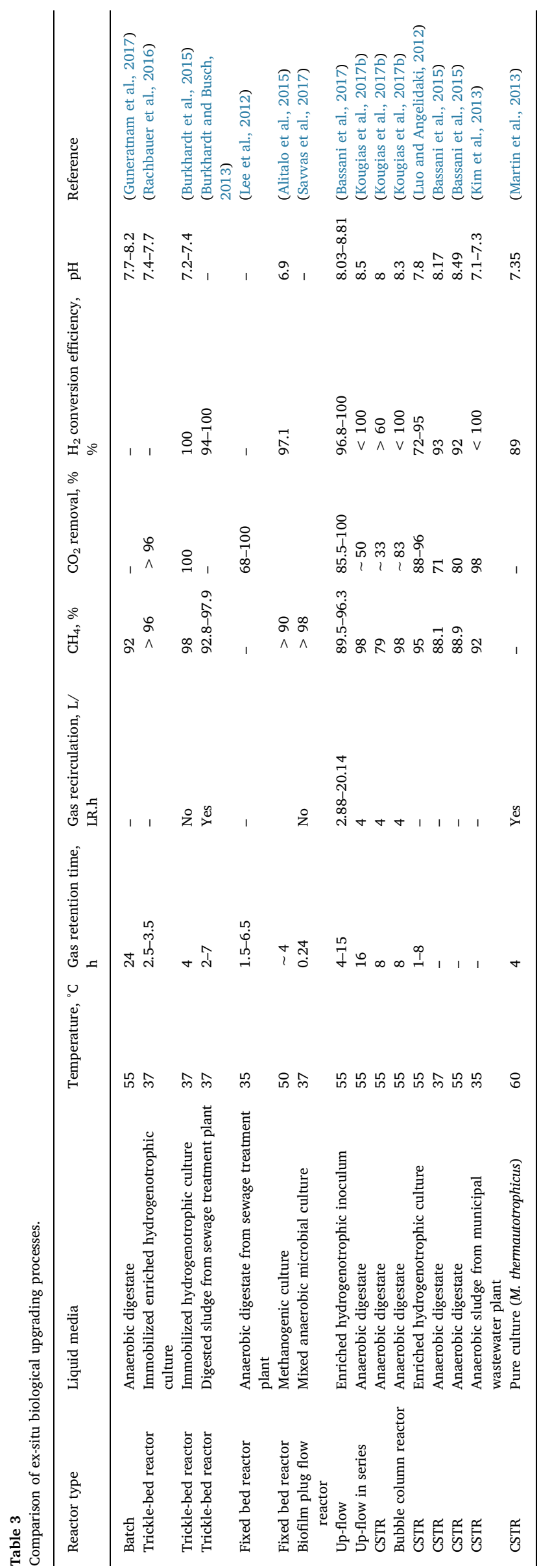


where $r_{t}$ is the $\mathrm{H}_{2}$ gas-liquid mass transfer rate ( $L /\left(L_{\text {Reactor}}\right.$.day), 22.4 is the corresponding volume that occupies $1 \mathrm{~mol}$ of gas at standard condition of temperature and pressure $(\mathrm{L} / \mathrm{mol}), k_{L} a$ is the gas transfer coefficient $\left(\right.$ day $^{-1}$ ), $\mathrm{H}_{2 g}$ is the $\mathrm{H}_{2}$ concentration in the gas phase (mol/ L), and finally $\mathrm{H}_{2 l}$ expresses the dissolved $\mathrm{H}_{2}$ in the liquid phase (mol/ L). Therefore, it is obvious the $\mathrm{H}_{2}$ gas-liquid mass transfer rate is proportionally correlated with the $k_{L} a$, which in turn is dependent on specific operational parameters such as the gas recirculation flow (Guiot et al., 2011; Kougias et al., 2017b), the reactor configuration (Bassani et al., 2016; Kougias et al., 2017b), the installed diffusion device (Bassani et al., 2017; Díaz et al., 2015; Luo and Angelidaki, 2013b) and the stirring intensity (Luo and Angelidaki, 2013b, 2012).

A number of research publications are proposing different novel concepts for increased biomethanation efficiencies. A comparative summary of these configurations is given in Table 3. It was demonstrated that the operating temperature was important for the biomethanation efficiency. More specifically, it was shown that enriched thermophilic culture resulted in $>60 \%$ higher $\mathrm{H}_{2}$ and $\mathrm{CO}_{2}$ bioconversion compared to the mesophilic culture in batch assay (Luo and Angelidaki, 2012). Another study concluded that an increment of the operating temperature from $55^{\circ} \mathrm{C}$ to $65^{\circ} \mathrm{C}$ leads to more efficient biomethanation operation (Guneratnam et al., 2017). Nevertheless, independently from the temperature conditions, an adaptation period is needed for the microorganisms to be able to efficiently ferment the $\mathrm{CO}_{2}$ and $\mathrm{H}_{2}$ gasses. For example, in a recent study, it was shown that by operating a mesophilic trickle-bed reactor with immobilized hydrogenotrophic culture for a period of 8 months, it was possible to obtain an output gas with $\mathrm{CH}_{4}$ content over $96 \%$ (Rachbauer et al., 2016). The biomethanation efficiency achieved is similar to the one recorded under thermophilic conditions (Bassani et al., 2017; Luo and Angelidaki, 2012). The types of the reactor along with the application of gas recirculation or liquid mixing are other essential parameters for designing a biogas upgrading system. It was demonstrated that upflow in series or bubble column reactors are able to achieve higher than $98 \%$ methane concentration at the output gas, even by injecting the $\mathrm{H}_{2}$ through conventional spargers instead of advanced membrane modules (Kougias et al., 2017b). Moreover, in relation to other reactor types, trickle bed reactor systems can achieve an increased $\mathrm{CO}_{2}$ and $\mathrm{H}_{2}$ conversion efficiency up to $98-99 \%$ methane, due to the formation of biofilm of mixed anaerobic consortia that serves as a good biocatalyst for the completion of the process (Burkhardt et al., 2015; Savvas et al., 2017). Finally, intensive stirring speed (Luo and Angelidaki, 2012), or diffusion devices with pore sizes that create gas-bubbles able to mix the reactor demonstrate best kinetics and output gas quality (Bassani et al., 2017).

2.2.1.3. Microbial communities in biological biogas upgrading systems. In anaerobic digestion context, biological biogas upgrading can be obtained via two different processes (Fig. 4). The first one is mediated by hydrogenotrophic methanogenic archaea performing the direct conversion of $\mathrm{CO}_{2}$ to $\mathrm{CH}_{4}$ with the use of external $\mathrm{H}_{2}$ as a source of electrons. This pathway, known as hydrogenotrophic methanogenesis, is highly energetically favourable at $\mathrm{pH} \mathrm{7,} \mathrm{according}$ to Eq. (1), with negative Gibbs free energies (Stams and Plugge, 2009).

The second metabolism responsible for biogas upgrading is indirect; it involves homoacetogenic bacteria and is based on the conversion of $\mathrm{CO}_{2}$ to acetate via the Wood-Ljungdahl pathway, which is also an exergonic process (Eq. (4)). Subsequently, this low energy gain is compensated by acetoclastic methanogenic archaea that convert the acetic acid into $\mathrm{CH}_{4}$ (Eq. (5)).

$4 \mathrm{H}_{2}+2 \mathrm{CO}_{2} \rightarrow \mathrm{CH}_{3} \mathrm{COOH}+2 \mathrm{H}_{2} \mathrm{O} \quad \Delta G^{\circ \prime}=-104.5 \mathrm{~kJ} / \mathrm{mol}$

$\mathrm{CH}_{3} \mathrm{COOH} \rightarrow \mathrm{CH}_{4}+\mathrm{CO}_{2} \quad \Delta G^{\circ \prime}=-31.0 \mathrm{~kJ} / \mathrm{mol}$

Under standard methanogenic conditions, $\mathrm{H}_{2}$ derives from acetate oxidation (or syntrophic acetate oxidation) via an endergonic reaction and the energy loss is compensated when $\mathrm{H}_{2}$ partial pressure is kept low by hydrogenotrophic methanogens. In this case, the low $\mathrm{H}_{2}$ partial pressure is fundamental to enable proton reduction and energy conservation (Stams and Plugge, 2009).

Due to the crucial role of $\mathrm{H}_{2}$ concentration on equilibrium of biochemical reactions, addition of external $\mathrm{H}_{2}$ has a strong selective pressure on the microbial community, shaping its composition with a massive increase of both hydrogenotrophic methanogens and homoacetogenic species producing acetate from $\mathrm{H}_{2}$ and $\mathrm{CO}_{2}$, such as Acetobacterium woodii, Moorella thermoacetica and different species belonging to and Clostridium (Schuchmann and Müller, 2014). In contrast, exogenous addition of $\mathrm{H}_{2}$ is responsible for inhibiting syntrophic acetogens (involved in propionate and butyrate degradation) and syntrophic acetate oxidizers (SAO) (Demirel and Scherer, 2008).

Hydrogenotrophic methanogens are the key players for efficient biogas upgrading process and their abundance can be increased using different strategies (i.e. bioaugmentation with pure cultures or endogenous enrichment of hydrogenotrophic populations). For practical applications, the utilization of mixed adapted cultures is more advantageous compared to pure cultures because the $\mathrm{H}_{2}$ adapted microbial communities are more robust and do not require sterile conditions, which would add extra costs to the process. Moreover, the development of a microbial acclimatized consortium was found to be more efficient in $\mathrm{H}_{2}$ conversion, with larger yields of $\mathrm{CH}_{4}$ compared to utilization of pure cultures represented for example by $M$. thermoautotrophicum (Peillex et al., 1990). Finally, by using of mixed adapted cultures, the costs of growing specific strains in large quantities for the initial inoculation of full-scale digesters are avoided.

Microbial analysis performed during biogas upgrading, revealed that the most frequently found hydrogenotrophic methanogenic genera were Methanobacterium, Methanoculleus, Methanomicrobium and Methanothermobacter (Agneessens et al., 2017; Bassani et al., 2017; Luo and Angelidaki, 2013a; Mulat et al., 2017), whereas Methanosarcina and, more generally, acetoclastic methanogens are usually present at lower abundance (Agneessens et al., 2017; Bassani et al., 2015; Mulat et al., 2017). Methanobacterium and Methanothermobacter species were found to be dominant in various biogas upgrading configurations (i.e. recirculation liquid of upflow reactors, immobilized on trickle-bed reactor and on biofilm created on top of $\mathrm{H}_{2}$ diffuser surface) (Kougias et al., 2017b; Rachbauer et al., 2016). Recently, a provisional name as "Candidatus Methanoculleus thermohydrogenotrophicum" was given to a new hydrogenotrophic archaea species which was found to increase in abundance upon $\mathrm{H}_{2}$ in thermophilic reactors (Kougias et al., 2017a).

The limiting step in hydrogen assisted methanogenesis is not always the biological conversion catalyzed by the microbial species but more often the $\mathrm{H}_{2}$ diffusion in the liquid medium (Díaz et al., 2015). In the presence of high $\mathrm{H}_{2}$ concentrations, the hydrogenotrophic archaea consume $\mathrm{H}_{2}$ for $\mathrm{CH}_{4}$ production instead of using it for microbial growth (Reeve et al., 1997). This will in turn promote the formation of a close syntrophic association between methanogens and fermentative bacteria. In fact, Reeve and colleagues found a decreased growth yield $\left(\mathrm{Y}_{\mathrm{CH} 4}\right)$ of $M$. thermoautotrophicum at high $\mathrm{H}_{2}$ concentration (expressed as grams of biomass synthesized per mole of $\mathrm{CH}_{4}$ produced), which was partially attributed to the transcriptional activity of some specific genes involved in methanogenesis (Reeve et al., 1997). Due to the difficulty in isolation and cultivation of methanogens and syntrophic bacterial species, most of the studies recently performed on these microbial communities were performed using high throughput 16S rRNA amplicon sequencing (Agneessens et al., 2017; Bassani et al., 2017; Kougias et al., 2017b; Mulat et al., 2017). It has been shown that $\mathrm{H}_{2}$ addition has multiple effects on the microbial species and it can influence not only species abundance but also their transcriptional activity (Reeve et al., 1997). For this reason a thorough investigation requires more complete analyses of the gene expression level performed using metatranscriptomic approaches. Among other results, analysis of the gene expression evidenced that hydrogenotrophic methanogenesis was 


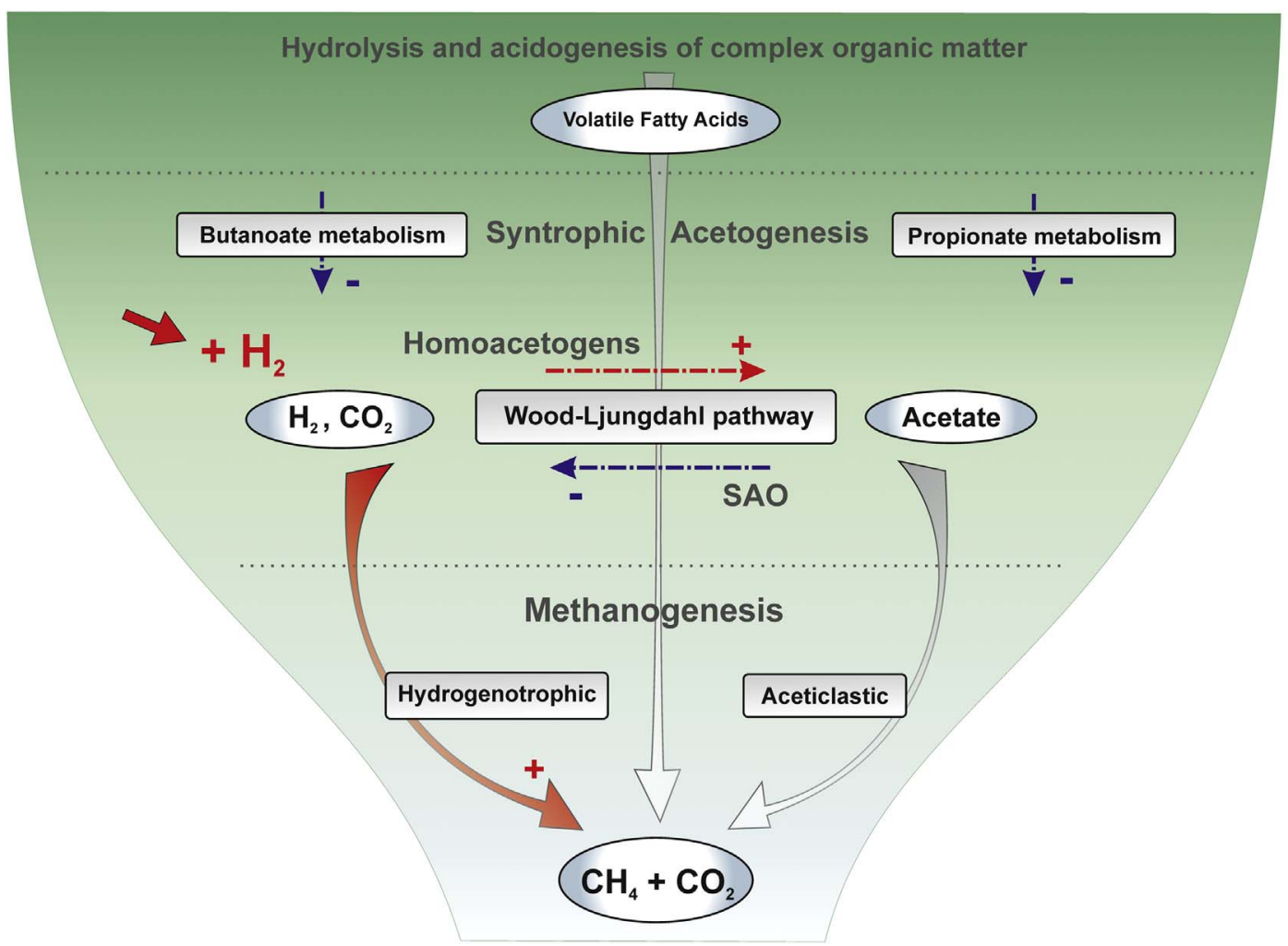

Fig. 4. Metabolic pathways for hydrogen assisted methanogenesis.

highly expressed in biogas reactors (Bremges et al., 2015; Treu et al., 2016) suggesting this as a possible explanation for the efficiency of methanogens in $\mathrm{H}_{2}$ utilization.

\subsubsection{Photoautotrophic methods}

The photosynthetic biogas upgrading is an alternative method to sequester the $\mathrm{CO}_{2}$ in order to obtain a $\mathrm{CH}_{4}$-rich gas. As presented in Table 4, by these methods $\mathrm{H}_{2} \mathrm{~S}$ removal is additionally achieved, while $>54 \%$ of $\mathrm{CO}_{2}$ is consumed. The methane recovery of photoautotrophic technologies can reach up to approximately $97 \%$ depending on the reactor type and the selected algal species. This biotechnological process is catalyzed by phototrophic organisms like algae in enclosed (e.g. tubular) or open (e.g. high rate algal ponds) photobioreactors (Table 4). Specifically, the closed systems have high photosynthetic performance and low requirements in terms of land and water needs, but their high investment cost and energy demands appear as the main bottlenecks. In contrast, the pros and cons of open photobioreactors differ markedly, as they need insignificant resources for construction and operation but they have lower photosynthetic $\mathrm{CO}_{2}$ uptake and higher natural sources requirements. In the upgrading process, the biogas is injected either directly in the photobioreactors or externally in an absorption column where microalgal broth stream is recirculated from the major tank. Subsequently, photoautotrophic microorganisms, as for instance prokaryotic cyanobacteria or eukaryotic microalgae, can efficiently uptake $\mathrm{CO}_{2}$ utilizing solar irradiation, water and nutrients to produce biomass, oxygen and heat. Thus, the $\mathrm{CH}_{4}$

Table 4

Comparison of different photoautotrophic biogas upgrading technologies.

\begin{tabular}{|c|c|c|c|c|c|c|c|}
\hline $\begin{array}{l}\text { Indoor/ } \\
\text { outdoor }\end{array}$ & System & Species & $\mathrm{H}_{2} \mathrm{~S}$ removal & $\begin{array}{l}\mathrm{CO}_{2} \text { removal, } \\
\%\end{array}$ & $\mathrm{O}_{2}, \%$ & $\begin{array}{l}\mathrm{CH}_{4} \text { recovery, } \\
\%\end{array}$ & Reference \\
\hline Indoor & HRAP & Chlorella vulgaris & Yes & $80 \%$ & $<2$ & & (Serejo et al., 2015) \\
\hline Indoor & HRAP & $\begin{array}{l}\text { Planktolynga brevicellularis (81\%), } \\
\text { Stigeoclonium tenue }(14 \%) \text { and } \\
\text { Limnothrix planktonica }(5 \%)\end{array}$ & Yes & $72-79$ & $1.2-0.7$ & 81 & (Posadas et al., 2015) \\
\hline \multirow[t]{3}{*}{ Outdoor } & Enclosed photobioreactor & Chlorella vulgaris & & 55.39 & & 80.4 & (Zhao et al., 2015) \\
\hline & bag & Scenedesmus obliquus & & 62.31 & 0.62 & 82.64 & \\
\hline & & Neochloris oleoabundans & & 54.39 & & 80.06 & \\
\hline Indoor & Open photobioreactor & Nannochloropsis gaditana & & 81 & 1.2 & & (Meier et al., 2015) \\
\hline Outdoor & HRAP & Picochlorumsp. and Halospirulina sp. & Yes & 94 & 2.6 & & $\begin{array}{l}\text { (Franco-Morgado } \\
\text { et al., 2017) }\end{array}$ \\
\hline Indoor & Enclosed photobioreactor & $\begin{array}{l}\text { Scenedesmus spp. } \\
\text { Mixotrophic } \\
\text { Autotrophic }\end{array}$ & Yes & 66.7 & 17.8 & 64.7 & (Prandini et al., 2016) \\
\hline Indoor & HRAP & Mychonastes homosphaera & Yes & 98.8 & 0.7 & 96.2 & $\begin{array}{l}\text { (Toledo-Cervantes } \\
\text { et al., 2017) }\end{array}$ \\
\hline Indoor & HRAP & $\begin{array}{l}\text { Geitlerinema sp. (61.5\%), Staurosira sp. (1.5\%) } \\
\text { and Stigeoclonium tenue }(37 \%)\end{array}$ & Yes & 98.8 & 0.03 & 97.2 & $\begin{array}{l}\text { (Toledo-Cervantes } \\
\text { et al., 2016) }\end{array}$ \\
\hline \multirow[t]{2}{*}{ Outdoor } & HRAP & Chlorella sp. & Yes & 95 & $0.1-2.0$ & 94 & (Posadas et al., 2017) \\
\hline & Open-photobioreactor & Chlorella sorokiniana & & 89-93 & $<1$ & & (Meier et al., 2017) \\
\hline
\end{tabular}


content is increased satisfying the existing regulations of having maximal 2-6\% $\mathrm{CO}_{2}$ in the final gas (Meier et al., 2015). Moreover, side benefit of this method is the production of active biomass that can be used either for the extraction of high value added products (Guedes et al., 2011) or as feedstock for biogas production oriented to circular economy (Mussgnug et al., 2010). Hence, the $\mathrm{CO}_{2}$ is efficiently valorised and transformed into other products and is not simply entrapped in the liquid media.

Interestingly, a variety of cyanobacteria or microalgae with high photosynthetic efficiency were successfully utilized for biomethane production among which Chlorella, Arthrospira and Spirulina species to be the most commonly studied (Muñoz et al., 2015). For instance, Chlorella sp. MB-9 (Kao et al., 2012a), Arthrospira platensis (Kao et al., 2012a), Spirulina platensis (Bahr et al., 2013) upgraded the biogas to $\mathrm{CH}_{4}$ concentration up to $90 \%, 82 \%$ and $74 \%$, respectively, while they performed a parallel photosynthetic $\mathrm{CO}_{2}$ assimilation of $85 \%, 100 \%$, and $86 \%$, respectively.

Apart from the $\mathrm{CO}_{2}$ consumption, the removal of other biogas pollutants is also of high importance. For instance, the efficiency of photoautotrophic technology is not favoured using pure microalgal photobioreactors due to the fact that the fixation of $1 \mathrm{~mol}$ of $\mathrm{CO}_{2}$ stoichiometrically leads to $1 \mathrm{~mol}$ of released $\mathrm{O}_{2}$, and thus, the composition of the final product is negatively affected (Meier et al., 2017). However, this drawback can be turned into advantage utilizing diverse cultures. On this context, Bahr et al. (2013) used a mixed consortium of microalgae and sulphur-oxidizers in order to oxidize the containing $\mathrm{H}_{2} \mathrm{~S}$ of the injected biogas to sulphate using the generated $\mathrm{O}_{2}$ as an electron acceptor. Hence, the calorific value of biomethane can be further improved by the combined $\mathrm{CO}_{2}$ capture and $\mathrm{H}_{2} \mathrm{~S}$ removal. In parallel, $\mathrm{H}_{2} \mathrm{~S}$ removal is very important for increased process sustainability as even at concentrations close to $100 \mathrm{ppmv}$ can be toxic to the microalgal cells (Kao et al., 2012b). Similarly, the surplus of $\mathrm{CO}_{2}$ can also slow down the microalgal growth rate driven by a $\mathrm{pH}$ drop (Meier et al., 2015). In another concept the produced gas consisting of methane and oxygen was utilized for production of single cell proteins by methanotrophs (van der Ha et al., 2011).

In addition, other operational conditions, such as temperature and dissolved oxygen concentrations, directly affect algal growth and thus, indirectly the upgrading efficiency (Muñoz and Guieysse, 2006). Furthermore, light wavelength and intensity are known to highly influence the photoautotrophic populations. On this topic, artificial light source using various LED strategies seem to be more promising for biogas upgrading purposes than natural solar light due to regulated light wavelengths, photoperiods and intensities towards optimal conditions (Yan et al., 2016). Finally, the gas retention time (Muñoz et al., 2015) and liquid to biogas ratio are additional technical parameters that should be always carefully considered to produce biomethane that compiles with the specifications of national legislations (ToledoCervantes et al., 2016).

\subsubsection{Biogas upgrading through other fermentation processes}

Although $\mathrm{CO}_{2}$ in biogas can be biologically converted to methane with the addition of $\mathrm{H}_{2}$ to achieve biogas upgrading, the production of valuable liquid products (e.g. acetate, ethanol, butyrate, butanol, etc.) from $\mathrm{CO}_{2}$ in biogas is more attractive (Agler et al., 2011; Kennes et al., 2016). The produced fatty acids such as acetate and butyrate are also important precursors for liquid biofuels production (Agler et al., 2011; Martin et al., 2016; Zhang et al., 2013). Diverse microorganisms (e.g. Acetobacterium woodii, Butyribacterium methylotrophicumn, Clostridium scatologenes, etc.) are known to be able to convert $\mathrm{CO}_{2}$ and $\mathrm{H}_{2}$ to liquid products (Schiel-Bengelsdorf and Dürre, 2012), and most of the microorganisms are acetogens, which assimilate $\mathrm{CO}_{2}$ by Wood-Ljungdahl pathway (also known as reductive acetyl-CoA pathway) (Latif et al., 2014). A homoacetogic strain Blautia coccoides GA-1 was isolated from a continuously stirred tank reactor (CSTR) treating organic wastewater, which could produce acetate from $\mathrm{CO}_{2}$ and $\mathrm{H}_{2}$ with the acetate yield of
$5.32 \mathrm{~g} / \mathrm{g}$ dry cell weight after $240 \mathrm{~h}$ of incubation (Liu et al., 2015). The study also showed that the presence of fermentable organics (e.g. glucose) could repress autotrophic metabolism remarkably. The ethanol production from syngas, containing $\mathrm{H}_{2}$ and $\mathrm{CO}_{2}$, was studied in a trickle bed reactor with Clostridium ragsdalei as the microbial catalyst, which demonstrated the importance of gas-liquid mass transfer during the fermentation process (Devarapalli et al., 2016). However, the products consist not only of ethanol $(5.7 \mathrm{~g} / \mathrm{L})$, but also acetate $(12.3 \mathrm{~g} / \mathrm{L})$. Compared to the pure culture fermentation, the mixed culture fermentation of $\mathrm{CO}_{2}$ and $\mathrm{H}_{2}$ has potential advantages such as no need for sterilisation and possibility of using wastewaters for nutrients supply. It was also demonstrated in previous studies that $\mathrm{CO}_{2}$ and $\mathrm{H}_{2}$ could be converted to acetate by mixed culture (Nie et al., 2008, 2007). It should be noted that acetate has high solubility and is energy-intensive to be separated from the liquid (Perez et al., 2013). Therefore, it was proposed to produce medium chain fatty acids (caproate and caprylate) from $\mathrm{CO}_{2}$ and $\mathrm{H}_{2}$ (Zhang et al., 2013), which not only have better fuel value than bioethanol but also are easier to be separated from the liquid (Agler et al., 2012; Kucek et al., 2016). Zhang et al. (2013) demonstrated that medium chain fatty acids (caproate $(0.98 \mathrm{~g} / \mathrm{L})$ and caprylate $(0.42 \mathrm{~g} / \mathrm{L})$ ) could be produced from $\mathrm{CO}_{2}$ and $\mathrm{H}_{2}$ in hollow-fiber membrane biofilm reactor by mixed culture. However, acetate $(7.4 \mathrm{~g} / \mathrm{L})$ and butyrate $(1.8 \mathrm{~g} / \mathrm{L})$ with relatively high concentrations were also produced, indicating the low selectivity for medium chain fatty acids in such process. The above mentioned technologies for valuable liquid products production from $\mathrm{CO}_{2}$ and $\mathrm{H}_{2}$ have not been applied to biogas upgrading. The effects of impurities (e.g. $\mathrm{H}_{2} \mathrm{~S}$ ) in biogas on the above fermentation technologies need to be investigated, and also the methods to enhance the selectivity of the products remain to be explored.

Biogas upgrading by conversion of $\mathrm{CO}_{2}$ in biogas together with $\mathrm{H}_{2}$ has the inherent challenge that needs availability of cheap $\mathrm{H}_{2}$ sources. Alternative fermentation processes exist where $\mathrm{CO}_{2}$ is coupled with sugars to produce carboxylic acids. In this way, $\mathrm{CO}_{2}$ in biogas can be converted to succinic acid during the glucose fermentation by Actinobacillus succinogenes or any other bacteria capable of producing succinic acid (Zeikus et al., 1999), which is a four-carbon diacid with the chemical formula $\mathrm{C}_{4} \mathrm{H}_{6} \mathrm{O}_{4}$. Succinic acid is a platform chemical and a precursor for the synthesis of numerous commodities in agri-food, chemical, and pharmaceutical industries (e.g. chemicals (1,4-butanediol, tetrahydrofuran, 2-pyrrolidinone, and gamma-butyrolactone), green solvents (like 2-Methyltetrahydrofuran (2-MeTHF)) and biodegradable polymers (polybutylene succinate (PBS) and polyamides) (Cukalovic and Stevens, 2008). Gunnarsson et al. (2014) made the first investigation on the feasibility of biogas upgrading by integration with biosuccinic acid production utilizing the bacteria Actinobacillus succinogenes 130Z. It showed that slight over-pressure during fermentation was advantageous for increasing the solubility of $\mathrm{CO}_{2}$, and thereby increases the final succinic acid yield and titer, $\mathrm{CO}_{2}$ consumption rate, and $\mathrm{CH}_{4}$ purity. The methane content of $95 \%$ in the biogas was achieved by this technology. The technology is very promising compared to those based on $\mathrm{H}_{2}$, since $\mathrm{H}_{2}$ has low solubility and generally requires high energy to achieve high gas-liquid mass transfer (Luo et al., 2012). It is known that there are different bacteria (e.g. Saccharomyces cerevisiae, Escherichia coli, etc. (van Heerden et al., 2013; Yan et al., 2014) that can produce succinic acid from glucose. Therefore, further studies are needed to identify other bacteria for succinic acid production coupled with biogas upgrading.

\subsubsection{Biogas upgrading through microbial electrochemical methods}

$\mathrm{CO}_{2}$ removal in biogas to produce $\mathrm{CH}_{4}$ by bioelectrochemical systems has been presented as sustainable and cost-effective way to upgrade biogas (Lovley and Nevin, 2013; Van Eerten-Jansen et al., 2012). In a microbial electrolysis cell (MEC), electrons released by bacteria from the oxidation of organics in anode can combine with protons to generate hydrogen in the cathode chamber (Lu and Ren, 2016; Zhang 
and Angelidaki, 2014). The hydrogen formed in the cathode can be used for biogas upgrading. In fact, Cheng et al. (2009) for the first time reported that methane could directly be produced by the reduction of $\mathrm{CO}_{2}$ in the cathode using a biocathode in MEC, and methane was produced at an overall energy efficiency of $80 \%$, which provided a potential technology for biogas upgrading. It was also demonstrated later that the reduction of $\mathrm{CO}_{2}$ to methane was attributed to both extracellular electron transfer and abiotically produced hydrogen (water electrolysis), which was dependent on the set potential of cathode (Villano et al., 2010). Later, biogas upgrading by MEC was studied by Xu et al. (2014), and both in-situ (the cathode of MEC was used as biogas reactor) and ex-situ (biogas was introduced to the cathode) biogas upgrading methods were tested. The removal of $\mathrm{CO}_{2}$ by in-situ biogas upgrading method was found to be better than ex-situ biogas upgrading method in both batch and continuous experiments, and the $\mathrm{CO}_{2}$ content in the biogas below $10 \%$ were obtained by both methods. Interestingly, it was found that the $\mathrm{CO}_{2}$ removal was attributed to not only the production of methane but also the $\mathrm{CO}_{2}$ ionisation due to alkalinity generated in the cathode.

Recently, another method was presented, in which the $\mathrm{CO}_{2}$ was removed from the gas to a separate chamber (Zeppilli et al., 2016). The comparison of MEC equipped with proton exchange membrane (PEM) and anion exchange membrane (AEM) for the $\mathrm{CO}_{2}$ removal from simulated biogas was conducted (Zeppilli et al., 2016). It was found that PEM-MEC showed higher COD removal efficiency $(78 \pm 7 \%)$ and methane production rate $(83 \pm 24 \mathrm{meq} / \mathrm{Ld})$ but needed more energy per unit of removed $\mathrm{CO}_{2}\left(2.36\right.$ vs $\left.0.78 \mathrm{kWh} / \mathrm{Nm}^{3} \mathrm{CO}_{2 \text { removed }}\right)$ than AEM-MEC. The main $\mathrm{CO}_{2}$ removal mechanism was the sorption of $\mathrm{CO}_{2}$ converted to bicarbonate due to the generation of alkalinity, and also part of the bicarbonate was transferred to anode in AEM-MEC, which might be related with its lower methane production rate. It should be noted that organic wastewater is not necessary in the anode since electricity can provide electrons from water, for $\mathrm{CO}_{2}$ reduction in the cathode, which was also demonstrated in a previous study (Van EertenJansen et al., 2012). It was found that oxygen produced in the anode during water oxidation could diffuse into the cathode, and therefore decreased the coulombic efficiency of the biocathode. However, the diffusion of oxygen to cathode did not have obvious negative effect on the methane production rate.

The production of valuable liquid products from $\mathrm{CO}_{2}$ can also be achieved in MEC (Sadhukhan et al., 2016; Wang and Ren, 2013). The reduction of $\mathrm{CO}_{2}$ to formic acid by using multiwalled carbon nanotubes and cobalt tetra-amino phthalocyanine as the cathode in MEC was reported previously (Zhao et al., 2012). In addition, biocathode immobilized by Methylobacterium extorquens $A M 1$ was also shown to be promise for formic acid production from $\mathrm{CO}_{2}$ (Hwang et al., 2015). Furthermore, Nevin et al. (2010) reported the production of acetate and 2-oxobutyrate from $\mathrm{CO}_{2}$ in a MEC with Sporomusa Ovata growing on the cathode, and enriched mixed culture grown on the cathode was also feasible for acetate production from $\mathrm{CO}_{2}$ in MEC (Xiang et al., 2017). It is obvious microbial electrochemical method is an environmentalfriendly way to couple several positive actions together, including consumption of $\mathrm{CO}_{2}$ to upgrade biogas, COD removal in the anode and production of valuable gas and liquid products. However, most of the current researches are based on lab-scale experiments; the technical and economic limitations for scaling up of the technologies for biogas upgrading remain to be explored.

\section{The incentives and feasibility of biogas upgrading}

The incentive for biogas upgrading relate to the larger scale transition of energy systems to renewable energy that is presently pursued by many countries. When releasing the energy supply from fossil fuels, the nature of the energy system changes towards a high share of fluctuating energy from wind and solar power and towards a high dependency on biomass resources (Danish Energy Agency, 2014a; Lund et al., 2011). With respect to the role of biogas in the energy system, this creates economic and environmental incentives for biogas upgrading. On the short term, upgrading by physical/chemical $\mathrm{CO}_{2}$ removal is both economically and environmentally attractive, in some countries this is already the case. On the longer term, in a global larger scale renewable energy scenario, also upgrading by hydrogenation is judged to be both environmentally and economically attractive to other non-fossil alternatives. The reasoning for these statements is found in the following sections.

\subsection{Feasibility of physicochemical $\mathrm{CO}_{2}$ removal}

Biogas upgrading by physicochemical $\mathrm{CO}_{2}$ removal is rapidly developing in many countries (Fig. 1b). As it can be illustrated by the case of Denmark, this is mainly due to the economical pay off compared to producing electricity and/or heat directly from the raw biogas. Fluctuating electricity production from wind power has in Denmark increased to a level close to $50 \%$, meaning that wind power production equals $50 \%$ of total electricity consumption on an annual basis. With a high share of fluctuating wind power, the relative benefit of biogas upgrading compared to heat/power production from the raw biogas increases, because the heat/power production must run continuously as raw biogas cannot cost-efficiently be stored for more than a few hours, whereas the upgraded gas can be stored on the gas grid for months. Storing the gas provides the flexibility and added value of using it in periods of highest value. It is foreseen that all new biogas plants in Denmark are likely to upgrade and store the gas on the grid (Danish Energy Agency, 2014b). Also with respect to environmental impacts, the upgrading applications are more beneficial compared to direct heat/power production. This can be explained by the fact that the continuous generation of heat/power increasingly replaces wind or solar power and biomass; however, stored $\mathrm{CH}_{4}$ allows replacing fossil based transport fuels and fossil electricity marginal supply, especially in periods with low wind (Wenzel et al., 2014).

The cost of upgrading is highly dependent on the biogas flow and the economy of investment scale (Fig. 5). Whereas Fig. 5a reflects the spectrum of investment costs of all types of physicochemical upgrading technologies on the market, Fig. 5b provides the total amortized investment (CAPEX) plus operation and maintenance costs (OPEX) pr. kWh of upgraded biogas for small scale pressure swing adsorption units (PSAs). An upgrading cost of e.g. $2 € \mathrm{c} / \mathrm{kWh}$ of upgraded biogas shall be seen relative to a sales price including subsidy of around $8.4 € \mathrm{c} / \mathrm{kWh}$ in Denmark in e.g. 2017. This upgrading cost allows selling the gas directly to the grid and, thus, further saves the investment in gas motor or turbine for heat/power production for new biogas facilities, where such a unit is not already installed. According to a recent study from EA Energianalyse and SDU (2016) the total cost of biogas upgraded by physicochemical $\mathrm{CO}_{2}$ removal (including OPEX and all amortized CAPEX) is found to lie in the interval $5.8-7.8 € \mathrm{c} / \mathrm{kWh}$ of upgraded biogas.

\subsection{Incentives for physicochemical or biological biogas upgrading}

Upgrading the raw biogas by reacting $\mathrm{CO}_{2}$ with $\mathrm{H}_{2}$ is more expensive than $\mathrm{CO}_{2}$ removal per $\mathrm{kWh}$ of biomethane produced due to the relative high cost of $\mathrm{H}_{2}$. Compared to a production cost of around $7 € \mathrm{c} /$ $\mathrm{kWh}$ of total upgraded biogas by $\mathrm{CO}_{2}$ removal, the cost of $\mathrm{H}_{2}$ itself lies around $9 € \mathrm{c} / \mathrm{kWh}$, and on top of this comes the investment in and operation of a methanation plant which adds a further $15-20 \%$ on this cost. This means that a total cost of biomethane from hydrogenating the $\mathrm{CO}_{2}$ part of raw biogas (assuming a $60 \% / 40 \% \mathrm{CH}_{4} / \mathrm{CO}_{2} \mathrm{mix}$ ) by physicochemical hydrogenation lies around $8-9 € \mathrm{c} / \mathrm{kWh}$ (EA Energianalyse and SDU, 2016). The cost of the biological hydrogenation is difficult to be concretely estimated, but is believed to be similar to physicochemical upgrading at present, as the cost of $\mathrm{H}_{2}$ is judged to be dominating in both cases. 


\section{(a) Specific investment cost $\left(€ /\left(\mathrm{Nm}^{3} / \mathrm{h}\right)\right)$}

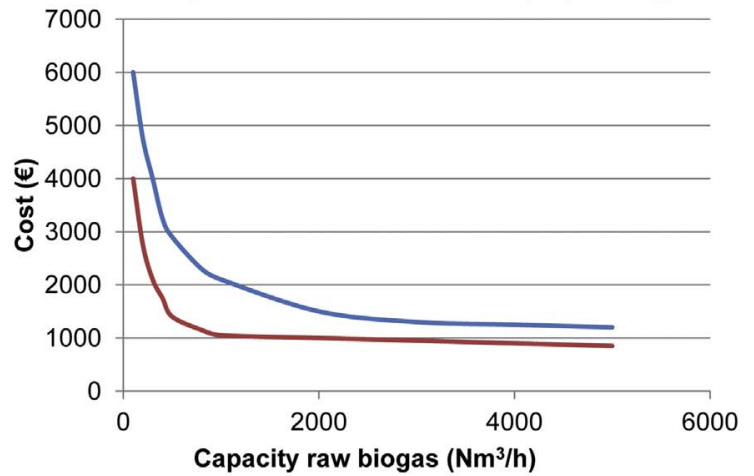

(b) Specific upgrading cost ( $€ \mathrm{c} / \mathrm{kWh}$ biogas)

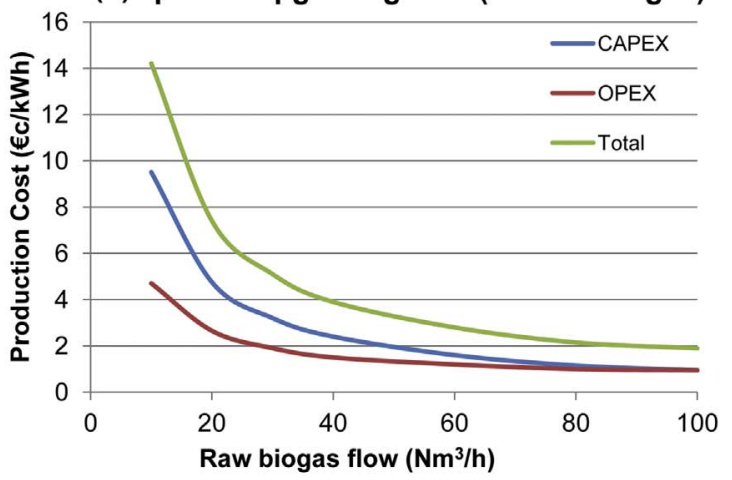

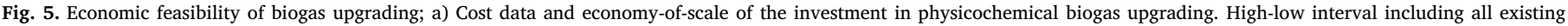

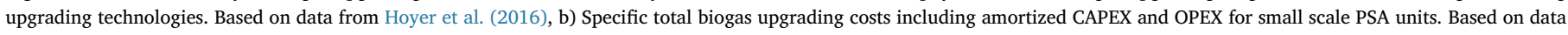
from Blom et al. (2011).

However, a rapid decrease in production cost of renewable electricity, both solar power and wind power, was experienced during the last decade and is expected to continue. In the decade 2005 to 2014, the cost of photovoltaic power production fell from $40 € \mathrm{c} / \mathrm{kWh}$ to $9 € \mathrm{c} /$ $\mathrm{kWh}$ under German solar radiation conditions, and this trend is expected to continue without any foreseeable levelling out and be around $2-4 € \mathrm{c} / \mathrm{kWh}$ in 2050 by a conservative estimate (Fraunhofer, 2015). This cost may turn to end up even lower. With rapidly decreasing renewable electricity production cost, the CAPEX part of the cost becomes more dominating. This means that on a longer term, the future winning technology will probably be found as the one with lowest CAPEX, but if this turns out to be microbiological upgrading or physicochemical upgrading is yet too early to say.

The incentive for upgrading biogas by $\mathrm{H}_{2}$ is, thus, not a short term economic benefit as it already is for physicochemical $\mathrm{CO}_{2}$ removal. But on a medium to longer term, further incentives are expected to evolve, both in terms of the just described fall in electricity production price and in terms of potential increase in biomass and gas prices relative to electricity price. Biogas hydrogenation may, thus, prove to be a key to a sustainable renewable energy system due to its ability to release energy systems from being over-dependent on biomass supply. Refraining from using fossil resources implies a challenge in providing propulsion means for a larger part of the transport sector, which cannot be electrified within a foreseeable future, i.e. aviation and long distance heavy duty transport on road and sea. If not based on fossil fuels, the most attractive source of carbon for hydrocarbon transport fuels is biomass, but comparing demand and supply potentials for hydrocarbon fuels and biomass shows that biomass must be considered a constrained resource (Wenzel et al., 2014). The most recent expert consensus on the global availability of biomass for energy is found in a report from the Intergovernmental Panel on Climate Change, IPCC (Chum et al., 2011), and it concludes that biomass available for energy will lie in the region of $100-300 \mathrm{EJ} /$ year in 2050, equal to around $10-30 \mathrm{GJ} /$ person/year at that time. To understand the significance of this figure, one can compare it to the scale of biomass demand in a renewable energy system design. In the last 5-10 years a large number of scenarios for a fully renewable energy system were made in Denmark. The developed energy system design, all being based on $100 \%$ renewable energy, vary from some being very dependent on biomass and bioenergy on the one side to some being very advanced with a high degree of electrification of heat and transport sectors and a high integration of electrolysis and $\mathrm{H}_{2}$. All the scenarios with large scale $\mathrm{H}_{2}$ assume that it is used for hydrogenation of carbon from biomass, both in the form of $\mathrm{CO}_{2}$ in biogas and in syngas from thermal gasification of wood.

Even though the studies were done independently and by different parties using different methods and modelling tools at different time points, there is an interesting consensus among these studies. The system designs being very dependent on biomass and bioenergy all need above $100 \mathrm{GJ} /$ person/year of biomass resources to satisfy the system demands. When the system reaches a high degree of electrification, the demand falls to around $80 \mathrm{GJ} /$ person/year (still without $\mathrm{H}_{2}$ ), and when large scale electrolysis and $\mathrm{H}_{2}$ is integrated, the demand falls to $40-50 \mathrm{GJ} /$ person/year. The scenarios with the lowest biomass demand assume even hydrogenation of $\mathrm{CO}_{2}$ (Lund et al., 2011; Mathiesen et al., 2015; Wenzel et al., 2014). A summary of $\mathrm{H}_{2}$ integration and biomass demand in these studies is given in Table 5.

As evident from Table 5, it seems that even very advanced renewable energy system designs with highest degree of electrification and large scale electrolysis and hydrogenation of bio-carbon implies a higher demand for biomass than the around $20 \mathrm{GJ} /$ person/year that is available as a global average according to Chum et al. (2011).

In this light, and as renewable energy is a targeted approach for meeting the climate challenge based on the agreement from the Climate Summit in Paris 2016, a strategy for including $\mathrm{H}_{2}$ for the upgrading of bio-carbon, including the $\mathrm{CO}_{2}$ of biogas, is judged to be an attractive approach to avoiding excessive demands for biomass for energy. The environmental benefit of avoiding excessive use of land for energy crops and forestry biomass is very large (Wenzel et al., 2014) and in a world of constrained biomass availability, hydrogenation may also prove to be economically favourable compared to excessive use of biomass and dependency on biomass imports.

Table 5

A summary of results regarding the relation between hydrogen integration and biomass demand in fully renewable energy system designs from Danish studies.

\begin{tabular}{|c|c|c|c|}
\hline \multirow[t]{2}{*}{ Study } & \multirow[t]{2}{*}{ Scenario } & Hydrogen & Biomass \\
\hline & & \multicolumn{2}{|c|}{ (GJ/person/year) } \\
\hline (Lund et al., 2011) & 'Recommended scenario' & 18 & 43 \\
\hline (Mathiesen et al., 2015) & & 19 & 43 \\
\hline $\begin{array}{l}\text { (Danish Energy Agency, } \\
\text { 2014a) }\end{array}$ & Bio + & 0 & 130 \\
\hline $\begin{array}{l}\text { (Danish Energy Agency, } \\
\text { 2014a) }\end{array}$ & Bio & 0 & 85 \\
\hline $\begin{array}{l}\text { (Danish Energy Agency, } \\
\text { 2014a) }\end{array}$ & Wind & 11 & 47 \\
\hline $\begin{array}{l}\text { (Danish Energy Agency, } \\
\text { 2014a) }\end{array}$ & Hydrogen & 15 & 44 \\
\hline (Wenzel et al., 2014) & Bio & 0 & 120 \\
\hline (Wenzel et al., 2014) & Electrification & 0 & 82 \\
\hline (Wenzel et al., 2014) & Electrolysis & 14 & 51 \\
\hline (Wenzel et al., 2014) & $\mathrm{CO}_{2}$ hydrogenation & 18 & 40 \\
\hline
\end{tabular}




\section{Perspectives - Conclusions}

Besides heat and power production, new applications of biogas have emerged the recent years. Conversion of biogas to biomethane is already a strategic target in many countries. Physicochemical methods are in general at high technology readiness levels, while biological methods are still new and not commercial yet. However, they offer huge potential in respect to feasibility, technological easiness, and potential. Development of biological technologies is rapid as challenges have been identified and solved. Biological upgrading opens new horizons for integrating different forms of renewable energy and besides upgrading can offer electricity storage advances and decoupling bioenergy production from biomass availability.

\section{Acknowledgement}

This work was supported by the Danish Council for Strategic Research under the project "SYMBIO - Integration of biomass and wind power for biogas enhancement and upgrading via hydrogen assisted anaerobic digestion", contract 12-132654, and by Energinet under the ForskEL project "2016-1-12465-BioUpgrade- Ex-situ biogas upgrading through biologically mediated $\mathrm{CO}_{2}$ reduction".

\section{References}

Abatzoglou, N., Boivin, S., 2009. A review of biogas purification processes. Biofuels Bioprod. Biorefin. 3, 42-71.

Agler, M.T., Wrenn, B.A., Zinder, S.H., Angenent, L.T., 2011. Waste to bioproduct conversion with undefined mixed cultures: the carboxylate platform. Trends Biotechnol. 29, 70-78.

Agler, M.T., Spirito, C.M., Usack, J.G., Werner, J.J., Angenent, L.T., 2012. Chain elongation with reactor microbiomes: upgrading dilute ethanol to medium-chain carboxylates. Energy Environ. Sci. 5, 8189.

Agneessens, L.M., Ottosen, L.D.M., Voigt, N.V., Nielsen, J.L., de Jonge, N., Fischer, C.H., Kofoed, M.V.W., 2017. In-situ biogas upgrading with pulse $\mathrm{H}_{2}$ additions: the relevance of methanogen adaption and inorganic carbon level. Bioresour. Technol. 233, $256-263$.

Alitalo, A., Niskanen, M., Aura, E., 2015. Biocatalytic methanation of hydrogen and carbon dioxide in a fixed bed bioreactor. Bioresour. Technol. 196, 600-605.

Andriani, D., Wresta, A., Atmaja, T.D., Saepudin, A., 2014. A review on optimization production and upgrading biogas through $\mathrm{CO}_{2}$ removal using various techniques. Appl. Biochem. Biotechnol. 172, 1909-1928.

Augelletti, R., Conti, M., Annesini, M.C., 2017. Pressure swing adsorption for biogas upgrading. A new process configuration for the separation of biomethane and carbon dioxide. J. Clean. Prod. 140, 1390-1398.

Awe, O.W., Zhao, Y., Nzihou, A., Minh, D.P., Lyczko, N., 2017. A review of biogas utilisation, purification and upgrading technologies. In: Waste and Biomass Valorization. vol. 8. pp. 267-283.

Bahr, M., Díaz, I., Dominguez, A., Gonzaíez Sachez, A., Muñ Oz, R., 2013. Microalgalbiotechnology as a platform for an integral biogas upgrading and nutrient removal from anaerobic effluents. Environ. Sci. Technol. 48, 573-581.

Baker, R.W., 2012. Membrane Technology and Applications, Second Edition. John Wiley \& Sons Ltd.

Bassani, I., Kougias, P.G., Treu, L., Angelidaki, I., 2015. Biogas upgrading via hydrogenotrophic methanogenesis in two-stage continuous stirred tank reactors at mesophilic and thermophilic conditions. Environ. Sci. Technol. 49, 12585-12593.

Bassani, I., Kougias, P.G., Angelidaki, I., 2016. In-situ biogas upgrading in thermophilic granular UASB reactor: key factors affecting the hydrogen mass transfer rate. Bioresour. Technol. 221, 485-491.

Bassani, I., Kougias, P.G., Treu, L., Porté, H., Campanaro, S., Angelidaki, I., 2017. Optimization of hydrogen dispersion in thermophilic up-flow reactors for ex situ biogas upgrading. Bioresour. Technol. 234, 310-319.

Batstone, D.J., Keller, J., Angelidaki, I., Kalyuzhnyi, S.V., Pavlostathis, S.G., Rozzi, A., Sanders, W.T., Siegrist, H., Vavilin, V.A., 2002. The IWA anaerobic digestion model no 1 (ADM1). Water Sci. Technol. 45, 65-73.

Bauer, F., Hulteberg, C., Persson, T., Tamm, D., 2013a. Biogas upgrading - review of commercial technologies. SGC Rapp. 270.

Bauer, F., Persson, T., Hulteberg, C., Tamm, D., 2013b. Biogas upgrading - technology overview, comparison and perspectives for the future. Biofuels Bioprod. Biorefin. 7, 499-511.

Bekkering, J., Broekhuis, A., van Gemert, W.J.T., 2010. Optimisation of a green gas supply chain-a review. Bioresour. Technol. 101, 450-456.

Blom, H., Mccann, M., Westman, J., 2012. Småskalig uppgradering och förädling av biogas. Rapport for Agroväst and Energigården. Agroväst, Skara.

Bremges, A., Maus, I., Belmann, P., Eikmeyer, F., Winkler, A., Albersmeier, A., Pühler, A., Schlüter, A., Sczyrba, A., 2015. Deeply sequenced metagenome and metatranscriptome of a biogas-producing microbial community from an agricultural production-scale biogas plant. Gigascience 4, 33.
Burkhardt, M., Busch, G., 2013. Methanation of hydrogen and carbon dioxide. Appl. Energy 111, 74-79.

Burkhardt, M., Koschack, T., Busch, G., 2015. Biocatalytic methanation of hydrogen and carbon dioxide in an anaerobic three-phase system. Bioresour. Technol. 178, 330-333.

Cheng, S., Xing, D., Call, D.F., Logan, B.E., 2009. Direct biological conversion of electrical current into methane by electromethanogenesis. Environ. Sci. Technol. 43, 3953-3958.

Chum, H., Faaij, A., Moreira, J., Berndes, G., Dhamija, P., Dong, H., Gabrielle, B., Eng, A.G., Lucht, W., Mapako, M., Cerutti, O.M., McIntyre, T., Minowa, T., Pingoud, K., 2011. Bioenergy. In: Edenhofer, O., Pichs-Madruga, R., Sokona, Y., Seyboth, K., Matschoss, P., Kadner, S., Zwickel, T., Eickemeier, P., Hansen, G., Schl $\varphi$ mer, S., von S, C. (Eds.), IPCC Special Report on Renewable Energy Sources and Climate Change Mitigation. Cambridge University Press, Cambridge.

Cukalovic, A., Stevens, C.V., 2008. Feasibility of production methods for succinic acid derivatives: a marriage of renewable resources and chemical technology. Biofuels Bioprod. Biorefin. 2, 505-529.

Danish Energy Agency, 2014a. Energiscenarier Frem Mod 2020, 2035 og 2050. ISBN: 978-87-93071-64-3. Available at: https://ens.dk/sites/ens.dk/files/ Basisfremskrivning/energiscenarier - analyse 2014 web.pdf.

Danish Energy Agency, 2014b. Biogas i Danmark - Status, Barrierer Og Perspektiver. ISBN: 978-87-93071-69-8. Available at: https://ens.dk/sites/ens.dk/files/Bioenergi/ biogas i danmark - analyse 2014-final.pdf.

Demirel, B., Scherer, P., 2008. The roles of acetotrophic and hydrogenotrophic methanogens during anaerobic conversion of biomass to methane: a review. Rev. Environ. Sci. Biotechnol. 7, 173-190.

Devarapalli, M., Atiyeh, H.K., Phillips, J.R., Lewis, R.S., Huhnke, R.L., 2016. Ethanol production during semi-continuous syngas fermentation in a trickle bed reactor using Clostridium ragsdalei. Bioresour. Technol. 209, 56-65.

Díaz, I., Pérez, C., Alfaro, N., Fdz-Polanco, F., 2015. A feasibility study on the bioconversion of $\mathrm{CO}_{2}$ and $\mathrm{H}_{2}$ to biomethane by gas sparging through polymeric membranes. Bioresour. Technol. 185, 246-253.

EA Energianalyse, SDU, 2016. Biogas Og Andre VE Braendstoffer Til Tung Transport. Available at: https://ens.dk/sites/ens.dk/files/Bioenergi/biogas_og_anden_ve_til tung_transport.pdf.

Franco-Morgado, M., Alcántara, C., Noyola, A., Muñoz, R., González-Sánchez, A., 2017. A study of photosynthetic biogas upgrading based on a high rate algal pond under alkaline conditions: influence of the illumination regime. Sci. Total Environ. 592, 419-425.

Fraunhofer, I.S.E., 2015. Current and future cost of photovoltaics. In: Long-term Scenarios for Market Development, System Prices and LCOE of Utility-Scale PV Systems. Study on behalf of Agora Energiewende.

Grande, C.A., Blom, R., 2014. Cryogenic adsorption of methane and carbon dioxide on zeolites 4A and 13X. Energy Fuel 28, 6688-6693.

Guebitz, G.M., Bauer, A., Bochmann, G., Gronauer, A., Weiss Editors, S., 2015. Biogas Science and Technology. Springer, Hannover, Germany.

Guedes, A., Amaro, H.M., Malcata, F.X., 2011. Microalgae as sources of high added-value compounds—a brief review of recent work. Biotechnol. Prog. 27, 597-613.

Guiot, S.R., Cimpoia, R., Carayon, G., 2011. Potential of wastewater-treating anaerobic granules for biomethanation of synthesis gas. Environ. Sci. Technol. 45, 2006-2012.

Guneratnam, A.J., Ahern, E., FitzGerald, J.A., Jackson, S.A., Xia, A., Dobson, A.D.W., Murphy, J.D., 2017. Study of the performance of a thermophilic biological methanation system. Bioresour. Technol. 225, 308-315.

Gunnarsson, I.B., Alvarado-Morales, M., Angelidaki, I., 2014. Utilization of $\mathrm{CO}_{2}$ fixating bacterium Actinobacillus succinogenes 130Z for simultaneous biogas upgrading and biosuccinic acid production. Environ. Sci. Technol. 48, 12464-12468.

Hoyer, K., Hulteberg, C., Svensson, M., Jernberg, J., Nörregård, Ö., 2016. Biogas Upgrading - Technical Review. Energiforsk.

Hwang, H., Yeon, Y.J., Lee, S., Choe, H., Jang, M.G., Cho, D.H., Park, S., Kim, Y.H., 2015. Electro-biocatalytic production of formate from carbon dioxide using an oxygenstable whole cell biocatalyst. Bioresour. Technol. 185, 35-39.

Jürgensen, L., Ehimen, E.A., Born, J., Holm-Nielsen, J.B., 2014. Utilization of surplus electricity from wind power for dynamic biogas upgrading: northern Germany case study. Biomass Bioenergy 66, 126-132.

Jürgensen, L., Ehimen, E.A., Born, J., Holm-Nielsen, J.B., 2015. Dynamic biogas upgrading based on the Sabatier process: thermodynamic and dynamic process simulation. Bioresour. Technol. 178, 323-329.

Kao, C.-Y., Chiu, S.-Y., Huang, T.-T., Dai, L., Hsu, L.-K., Lin, C.-S., 2012a. Ability of a mutant strain of the microalga Chlorella $s p$. to capture carbon dioxide for biogas upgrading. Appl. Energy 93, 176-183.

Kao, C.-Y., Chiu, S.-Y., Huang, T.-T., Dai, L., Wang, G.-H., Tseng, C.-P., Chen, C.-H., Lin, C.-S., 2012b. A mutant strain of microalga Chlorella sp. for the carbon dioxide capture from biogas. Biomass Bioenergy 36, 132-140.

Kennes, D., Abubackar, H.N., Diaz, M., Veiga, M.C., Kennes, C., 2016. Bioethanol production from biomass: carbohydrate vs syngas fermentation. J. Chem. Technol. Biotechnol. 91, 304-317.

Kim, S., Choi, K., Chung, J., 2013. Reduction in carbon dioxide and production of methane by biological reaction in the electronics industry. Int. J. Hydrog. Energy 38 3488-3496.

Kougias, P.G., Kotsopoulos, T.A., Martzopoulos, G.G., 2010. Anaerobic co-digestion of pig waste with olive mill waste water under various mixing conditions. Fresenius Environ. Bull. 19, 1682-1686.

Kougias, P.G., Campanaro, S., Treu, L., Zhu, X., Angelidaki, I., 2017a. A novel archaeal species belonging to methanoculleus genus identified via de-novo assembly and metagenomic binning process in biogas reactors. Anaerobe 46, 23-32.

Kougias, P.G., Treu, L., Benavente, D.P., Boe, K., Campanaro, S., Angelidaki, I, 2017b. Ex- 
situ biogas upgrading and enhancement in different reactor systems. Bioresour. Technol. 225, 429-437.

Kucek, L.A., Spirito, C.M., Angenent, L.T., 2016. High n-caprylate productivities and specificities from dilute ethanol and acetate: chain elongation with microbiomes to upgrade products from syngas fermentation. Energy Environ. Sci. 9, 3482-3494.

Latif, H., Zeidan, A.A., Nielsen, A.T., Zengler, K., 2014. Trash to treasure: production of biofuels and commodity chemicals via syngas fermenting microorganisms. Curr. Opin. Biotechnol. 27, 79-87.

Lee, J.C., Kim, J.H., Chang, W.S., Pak, D., 2012. Biological conversion of $\mathrm{CO}_{2}$ to $\mathrm{CH}_{4}$ using hydrogenotrophic methanogen in a fixed bed reactor. J. Chem. Technol. Biotechnol. 87, 844-847.

Liu, Y., Whitman, W.B., 2008. Metabolic, phylogenetic, and ecological diversity of the methanogenic archaea. Ann. N. Y. Acad. Sci. 1125, 171-189.

Liu, C., Li, J., Zhang, Y., Philip, A., Shi, E., Chi, X., Meng, J., 2015. Influence of glucose fermentation on $\mathrm{CO} 2$ assimilation to acetate in homoacetogen Blautia coccoides GA-1. J. Ind. Microbiol. Biotechnol. 42, 1217-1224.

Lovley, D.R., Nevin, K.P., 2013. Electrobiocommodities: powering microbial production of fuels and commodity chemicals from carbon dioxide with electricity. Curr. Opin. Biotechnol. 24, 385-390.

Lu, L., Ren, Z.J., 2016. Microbial electrolysis cells for waste biorefinery: a state of the art review. Bioresour. Technol. 215, 254-264.

Lund, H., Hvelplund, F., Vad Mathiesen, B., Alberg Østergaard, P., Christensen, P., Connolly, D., Schaltz, E., Pillay, R.J., Pagh Nielsen, M., Felby, C., Scott Bentsen, N., Tonini, D., Astrup, T., Meyer, N.I.K.H., Morthorst, P.E., Møller Andersen, F., Münster, M., Pade Hansen, L.L., Wenzel, H., Hamelin, L., Munksgaard, J., Karnøe, P., Lind, M., 2011. Coherent Energy and Environmental System Analysis. Aalborg University, Aalborg.

Luo, G., Angelidaki, I., 2012. Integrated biogas upgrading and hydrogen utilization in an anaerobic reactor containing enriched hydrogenotrophic methanogenic culture. Biotechnol. Bioeng. 109, 2729-2736.

Luo, G., Angelidaki, I., 2013a. Co-digestion of manure and whey for in situ biogas upgrading by the addition of $\mathrm{H}_{2}$ : process performance and microbial insights. Appl. Microbiol. Biotechnol. 97, 1373-1381.

Luo, G., Angelidaki, I., 2013b. Hollow fiber membrane based $\mathrm{H}_{2}$ diffusion for efficient in situ biogas upgrading in an anaerobic reactor. Appl. Microbiol. Biotechnol. 97, 3739-3744.

Luo, G., Johansson, S., Boe, K., Xie, L., Zhou, Q., Angelidaki, I., 2012. Simultaneous hydrogen utilization and in situ biogas upgrading in an anaerobic reactor. Biotechnol. Bioeng. 109, 1088-1094.

Luo, G., Wang, W., Angelidaki, I., 2014. A new degassing membrane coupled upflow anaerobic sludge blanket (UASB) reactor to achieve in-situ biogas upgrading and recovery of dissolved CH4 from the anaerobic effluent. Appl. Energy 132, 536-542.

Makaruk, A., Miltner, M., Harasek, M., 2010. Membrane biogas upgrading processes for the production of natural gas substitute. Sep. Purif. Technol. 74, 83-92.

Martin, M.R., Fornero, J.J., Stark, R., Mets, L., Angenent, L.T., 2013. A single-culture bioprocess of methanothermobacter thermautotrophicus to upgrade digester biogas by $\mathrm{CO}_{2}$-to- $\mathrm{CH}_{4}$ conversion with $\mathrm{H}_{2}$. Archaea 2013,157529 .

Martin, M.E., Richter, H., Saha, S., Angenent, L.T., 2016. Traits of selected Clostridium strains for syngas fermentation to ethanol. Biotechnol. Bioeng. 113, 531-539.

Mathiesen, B.V., Lund, H., Hansen, K., Skov, I.R., Djørup, S.R., Nielsen, S., Sorknæs, P., Thellufsen, J.Z., Grundahl, L., Lund, Rasmus Søgaard, Drysdale, D.W., Connolly, D., Østergaard, P.A., 2015. IDA's Energy Vision 2050: A Smart Energy System Strategy for 100\% Renewable Denmark, Department Development and Planning. Aalborg University, Aalborg.

MeGa-stoRE, 2016. Final Report od Project No 12006. [WWW Document] URL. http:// www.lemvigbiogas.com/MeGa-stoREfinalreport.pdf.

Meier, L., Pérez, R., Azócar, L., Rivas, M., Jeison, D., 2015. Photosynthetic $\mathrm{CO}_{2}$ uptake by microalgae: an attractive tool for biogas upgrading. Biomass Bioenergy 73, 102-109.

Meier, L., Barros, P., Torres, A., Vilchez, C., Jeison, D., 2017. Photosynthetic biogas upgrading using microalgae: effect of light/dark photoperiod. Renew. Energy 106, $17-23$.

Mulat, D.G., Mosbæk, F., Ward, A.J., Polag, D., Greule, M., Keppler, F., Nielsen, J.L. Feilberg, A., 2017. Exogenous addition of $\mathrm{H}_{2}$ for an in situ biogas upgrading through biological reduction of carbon dioxide into methane. Waste Manag. 68, 146-156.

Muñoz, R., Guieysse, B., 2006. Algal-bacterial processes for the treatment of hazardous contaminants: a review. Water Res. 40, 2799-2815.

Muñoz, R., Meier, L., Diaz, I., Jeison, D., 2015. A review on the state-of-the-art of physical/chemical and biological technologies for biogas upgrading. Rev. Environ. Sci. Biotechnol. 14, 727-759.

Mussgnug, J.H., Klassen, V., Schlüter, A., Kruse, O., 2010. Microalgae as substrates for fermentative biogas production in a combined biorefinery concept. J. Biotechnol. $150,51-56$.

Nevin, K.P., Woodard, T.L., Franks, A.E., Summers, Z.M., Lovley, D.R., 2010. Microbial electrosynthesis: feeding microbes electricity to convert carbon dioxide and water to multicarbon extracellular organic compounds. MBio 1, e00103-10.

Nie, Y., Liu, H., Du, G., Chen, J., 2007. Enhancement of acetate production by a novel coupled syntrophic acetogenesis with homoacetogenesis process. Process Biochem. 42, 599-605.

Nie, Y., Liu, H., Du, G., Chen, J., 2008. Acetate yield increased by gas circulation and fedbatch fermentation in a novel syntrophic acetogenesis and homoacetogenesis coupling system. Bioresour. Technol. 99, 2989-2995.

Peillex, J.-P., Fardeau, M.-L., Belaich, J.-P., 1990. Growth of methanobacterium thermoautotrophicum on $\mathrm{H}_{2}$ ? $\mathrm{CO}_{2}$ : high $\mathrm{CH}_{4}$ productivities in continuous culture. Biomass 21, 315-321.

Perez, J.M., Richter, H., Loftus, S.E., Angenent, L.T., 2013. Biocatalytic reduction of shortchain carboxylic acids into their corresponding alcohols with syngas fermentation.
Biotechnol. Bioeng. 110, 1066-1077.

Persson, M., 2003. Evaluation of upgrading techniques for biogas. Rep. SGC 142.

Petersson, A., Wellinger, A., 2009. Biogas upgrading technologies-developments and innovations. IEA Bioenergy 20.

Posadas, E., Serejo, M.L., Blanco, S., Perez, R., Garcia-Encina, P.A., Muñoz, R., 2015. Minimization of biomethane oxygen concentration during biogas upgrading in algalbacterial photobioreactors. Algal Res. 12, 221-229.

Posadas, E., Marín, D., Blanco, S., Lebrero, R., Muñoz, R., 2017. Simultaneous biogas upgrading and centrate treatment in an outdoors pilot scale high rate algal pond. Bioresour. Technol. 232, 133-141.

Prandini, J.M., da Silva, M.L.B., Mezzari, M.P., Pirolli, M., Michelon, W., Soares, H.M., 2016. Enhancement of nutrient removal from swine wastewater digestate coupled to biogas purification by microalgae Scenedesmus spp. Bioresour. Technol. 202, 67-75.

Rachbauer, L., Voitl, G., Bochmann, G., Fuchs, W., 2016. Biological biogas upgrading capacity of a hydrogenotrophic community in a trickle-bed reactor. Appl. Energy $180,483-490$.

Reeve, J., Morgan, R., Nolling, J., 1997. Environmental and molecular regulation of methanogenesis. Water Sci. Technol. 36, 1-6.

Ryckebosch, E., Drouillon, M., Vervaeren, H., 2011. Techniques for transformation of biogas to biomethane. Biomass Bioenergy 35, 1633-1645.

Sadhukhan, J., Lloyd, J.R., Scott, K., Premier, G.C., Yu, E.H., Curtis, T., Head, I.M., 2016. A critical review of integration analysis of microbial electrosynthesis (MES) systems with waste biorefineries for the production of biofuel and chemical from reuse of $\mathrm{CO}_{2}$. Renew. Sust. Energ. Rev. 56, 116-132.

Savvas, S., Donnelly, J., Patterson, T., Chong, Z.S., Esteves, S.R., 2017. Biological methanation of $\mathrm{CO} 2$ in a novel biofilm plug-flow reactor: a high rate and low parasitic energy process. Appl. Energy 202, 238-247.

Schiel-Bengelsdorf, B., Dürre, P., 2012. Pathway engineering and synthetic biology using acetogens. FEBS Lett. 586, 2191-2198.

Schuchmann, K., Müller, V., 2014. Autotrophy at the thermodynamic limit of life: a mode for energy conservation in acetogenic bacteria. Nat. Rev. Microbiol. 12, 809-821.

Serejo, M.L., Posadas, E., Boncz, M.A., Blanco, S., Garcia-Encina, P., Muñoz, R., 2015. Influence of biogas flow rate on biomass composition during the optimization of biogas upgrading in microalgal-bacterial processes. Environ. Sci. Technol. 49 3228-3236.

Stams, A.J.M., Plugge, C.M., 2009. Electron transfer in syntrophic communities of anaerobic bacteria and archaea. Nat. Rev. Microbiol. 7, 568-577.

Sun, Q., Li, H., Yan, J., Liu, L., Yu, Z., Yu, X., 2015. Selection of appropriate biogas upgrading technology-a review of biogas cleaning, upgrading and utilisation. Renew. Sust. Energ. Rev. 51, 521-532.

Thrän, D., Billig, E., Persson, T., Svensson, M., Daniel-Gromke, J., Ponitka, J., Seiffert, M., 2014. Biomethane-Status and Factors Affecting Market Development and Trade. IEA Task 40 and Task 37 Joint Study. Available at: http://task40.ieabioenergy.com/wpcontent/uploads/2013/09/t40-t37-biomethane-2014.pdf (accessed 18 January 2018).

Tirunehe, G., Norddahl, B., 2016. The influence of polymeric membrane gas spargers on hydrodynamics and mass transfer in bubble column bioreactors. Bioprocess Biosyst. Eng. 39, 613-626.

Toledo-Cervantes, A., Serejo, M.L., Blanco, S., Pérez, R., Lebrero, R., Muñoz, R., 2016. Photosynthetic biogas upgrading to bio-methane: boosting nutrient recovery via biomass productivity control. Algal Res. 17, 46-52.

Toledo-Cervantes, A., Madrid-Chirinos, C., Cantera, S., Lebrero, R., Muñoz, R., 2017. Influence of the gas-liquid flow configuration in the absorption column on photosynthetic biogas upgrading in algal-bacterial photobioreactors. Bioresour. Technol. 225, 336-342.

Treu, L., Campanaro, S., Kougias, P.G., Zhu, X., Angelidaki, I., 2016. Untangling the effect of fatty acid addition at species level revealed different transcriptional responses of the biogas microbial community members. Environ. Sci. Technol. 50, 6079-6090.

van der Ha, D., Bundervoet, B., Verstraete, W., Boon, N., 2011. A sustainable, carbon neutral methane oxidation by a partnership of methane oxidizing communities and microalgae. Water Res. 45, 2845-2854.

Van Eerten-Jansen, M.C.A.A., Ter Heijne, A., Buisman, C.J.N., Hamelers, H.V.M., 2012. Microbial electrolysis cells for production of methane from $\mathrm{CO}_{2}$ : long-term performance and perspectives. Int. J. Energy Res. 36, 809-819.

van Heerden, C.D., Nicol, W., Shanmugam, K., Yomano, L., York, S., Ingram, L., Ingram, L., Antonova, S., Sineoky, S., 2013. Continuous succinic acid fermentation by Actinobacillus succinogenes. Biochem. Eng. J. 73, 5-11.

Villano, M., Aulenta, F., Ciucci, C., Ferri, T., Giuliano, A., Majone, M., 2010. Bioelectrochemical reduction of $\mathrm{CO}_{2}$ to $\mathrm{CH}_{4}$ via direct and indirect extracellular electron transfer by a hydrogenophilic methanogenic culture. Bioresour. Technol. 101, 3085-3090.

Wang, H., Ren, Z.J., 2013. A comprehensive review of microbial electrochemical systems as a platform technology. Biotechnol. Adv. 31, 1796-1807.

Wang, W., Xie, L., Luo, G., Zhou, Q., Angelidaki, I., 2013. Performance and microbial community analysis of the anaerobic reactor with coke oven gas biomethanation and in situ biogas upgrading. Bioresour. Technol. 146, 234-239.

Wenzel, H., Høibye, L., Grandal, R.D., Hamelin, L., Olesen, A.S., 2014. Carbon footprint of bioenergy pathways for the future Danish energy system. Available at: https://ens. $\mathrm{dk} /$ sites/ens.dk/files/Bioenergi/carbon_footprint_of_bioeneergy_pathways_for_the_ future_danish_energy_system_-_final_210314_l.pdf.

Xia, A., Cheng, J., Murphy, J.D., 2016. Innovation in biological production and upgrading of methane and hydrogen for use as gaseous transport biofuel. Biotechnol. Adv. 34 $451-472$.

Xiang, Y., Liu, G., Zhang, R., Lu, Y., Luo, H., 2017. High-efficient acetate production from carbon dioxide using a bioanode microbial electrosynthesis system with bipolar membrane. Bioresour. Technol. 233, 227-235. 
Xu, H., Wang, K., Holmes, D.E., 2014. Bioelectrochemical removal of carbon dioxide $\left(\mathrm{CO}_{2}\right)$ : an innovative method for biogas upgrading. Bioresour. Technol. 173, 392-398.

Yan, D., Wang, C., Zhou, J., Liu, Y., Yang, M., Xing, J., 2014. Construction of reductive pathway in Saccharomyces cerevisiae for effective succinic acid fermentation at low $\mathrm{pH}$ value. Bioresour. Technol. 156, 232-239.

Yan, C., Muñoz, R., Zhu, L., Wang, Y., 2016. The effects of various LED (light emitting diode) lighting strategies on simultaneous biogas upgrading and biogas slurry nutrient reduction by using of microalgae Chlorella sp. Energy 106, 554-561.

Yoo, M., Sang-Jun, H., Jung-Ho, W., 2013. Carbon dioxide capture capacity of sodium hydroxide aqueous solution. J. Environ. Manag. 114, 512-519.

Zeikus, J.G., Jain, M.K., Elankovan, P., 1999. Biotechnology of succinic acid production and markets for derived industrial products. Appl. Microbiol. Biotechnol. 51, $545-552$.

Zeppilli, M., Lai, A., Villano, M., Majone, M., 2016. Anion vs cation exchange membrane strongly affect mechanisms and yield of $\mathrm{CO}_{2}$ fixation in a microbial electrolysis cell.
Chem. Eng. J. 304, 10-19.

Zhang, Y., Angelidaki, I., 2014. Microbial electrolysis cells turning to be versatile technology: recent advances and future challenges. Water Res. 56, 11-25.

Zhang, F., Ding, J., Zhang, Y., Chen, M., Ding, Z.-W., van Loosdrecht, M.C.M., Zeng, R.J., 2013. Fatty acids production from hydrogen and carbon dioxide by mixed culture in the membrane biofilm reactor. Water Res. 47, 6122-6129.

Zhao, Q., Leonhardt, E., Macconnell, C., Frear, C., Chen, S., 2010. Purification technologies for biogas generated by anaerobic digestion. In: Compress Biomethane, pp. $1-24$

Zhao, H., Zhang, Y., Zhao, B., Chang, Y., Li, Z., 2012. Electrochemical reduction of carbon dioxide in an MFC-MEC system with a layer-by-layer self-assembly carbon nanotube/ cobalt phthalocyanine modified electrode. Environ. Sci. Technol. 46, 5198-5204.

Zhao, Y., Sun, S., Hu, C., Zhang, H., Xu, J., Ping, L., 2015. Performance of three microalgal strains in biogas slurry purification and biogas upgrade in response to various mixed light-emitting diode light wavelengths. Bioresour. Technol. 187, 338-345. 